\title{
Study of the Inorganic Substitution in a Functionalized UiO-66 Metal-Organic Framework
}

\author{
Alhassan Salman Yasin
}

Follow this and additional works at: https://researchrepository.wvu.edu/etd

\section{Recommended Citation}

Yasin, Alhassan Salman, "Study of the Inorganic Substitution in a Functionalized UiO-66 Metal-Organic Framework" (2016). Graduate Theses, Dissertations, and Problem Reports. 7001.

https://researchrepository.wvu.edu/etd/7001

This Thesis is protected by copyright and/or related rights. It has been brought to you by the The Research Repository @ WVU with permission from the rights-holder(s). You are free to use this Thesis in any way that is permitted by the copyright and related rights legislation that applies to your use. For other uses you must obtain permission from the rights-holder(s) directly, unless additional rights are indicated by a Creative Commons license in the record and/ or on the work itself. This Thesis has been accepted for inclusion in WVU Graduate Theses, Dissertations, and Problem Reports collection by an authorized administrator of The Research Repository @ WVU. For more information, please contact researchrepository@mail.wvu.edu. 


\title{
Study of the Inorganic Substitution in a Functionalized UiO-66 Metal-Organic Framework
}

\author{
Alhassan Salman Yasin \\ Thesis submitted \\ to the Benjamin M. Statler College of \\ Engineering and Mineral Resources \\ at West Virginia University \\ in partial fulfillment of the requirements for the degree of \\ Master of Science \\ in \\ Mechanical and Aerospace Engineering
}

Terence Musho, Ph.D., Chair

Konstantinos Sieros, Ph.D.

Nianqiang $\mathrm{Wu}$, Ph.D.

Department of Mechanical and Aerospace Engineering

Morgantown, West Virginia

April, 2016

Keywords: Metal-Organic Framework (MOF), UiO-66, Band Gap Modulation

Copyright 2016 Alhassan Salman Yasin 


\title{
ABSTRACT \\ Study of the Inorganic Substitution in a Functionalized UiO-66 Metal-Organic Framework
}

\begin{abstract}
Alhassan Salman Yasin
Metal-Organic Frameworks (MOFs) have received considerable attention and fast development in the past few years. These materials have demonstrated a wide range of applications due to their porosity, tailorability of optical properties, and chemical selectivity. This report catalogs common MOF designs based on application and diversity in various fields, as well as conduct an in-depth study of inorganic substitution in a functionalized MOF.

This study investigates the band gap modulation in response to inorganic ion substitution within a thermally stable UiO-66 Metal-Organic Framework (MOF). A combination of density functional theory (DFT) predictions in conjunction with experimental predictions were used to map out the complete composition space for three inorganic ions ( $\mathrm{Zr}, \mathrm{Hf}, \mathrm{Ti}$ ) and three functional groups. The three functional groups include an amino group $\left(\mathrm{NH}_{2}\right)$, a nitro group $\left(\mathrm{NO}_{2}\right)$, and a hydrogenated case $(\mathrm{H})$. The smallest determined band gap was for a partially substituted $\mathrm{UiO}-66\left(\mathrm{Ti}_{5} \mathrm{Zr}_{1}\right)-\mathrm{NH}_{2}$ resulting in $2.60 \mathrm{eV}$. Theoretical findings support that $\mathrm{Ti}$ can be fully substituted within the lattice resulting in a predicted band gap as low as $1.62(2.77) \mathrm{eV}$. Band gap modulation was reasoned to be a result of a mid gap state introduced through the amino functionalization and HOMO shifting as a result of increased binding of the Ti-O-C bonds.
\end{abstract}




\section{TABLE OF CONTENTS}

Page

\section{Chapter}

1. INTRODUCTION . . . . . . . . . . . . . . . . . . 1

1.1 Background of MOF ................................. 1

1.2 Catalog of Common MOFs ........................... 3

1.3 Catalog of Known Catalytic MOFs ...................... 4

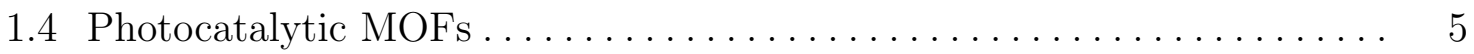

2. COMPUTATIONAL AND EXPERIMENTAL DETAILS . . . . . 7

2.1 Material Design ................................. 7

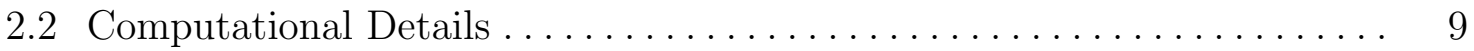

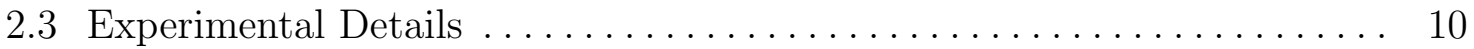

2.3.1 Experimental Synthesis . . . . . . . . . . . . . . . . . . . 10

3. RESULTS AND DISCUSSION . . . . . . . . . . . . . 15

3.1 Results and Discussion ............................. 15

4. CONCLUSION. .................. 23

REFERENCES. . . . . . . . . . . . . . . . . 24

Appendix

APPENDIX A . . . . . . . . . . . . . . . . 32

APPENDIX B . . . . . . . . . . . . . . . . . 55 


\section{LIST OF FIGURES}

Figure 2.1 Primitive Unit Cell and Linker Designs.................... 8

Figure 2.2 Cumulative UV-Vis Spectrum Plot $\ldots \ldots \ldots \ldots \ldots \ldots \ldots \ldots \ldots \ldots$

Figure 2.3 Exchange UV-Vis Spectrum Plot ....................... 13

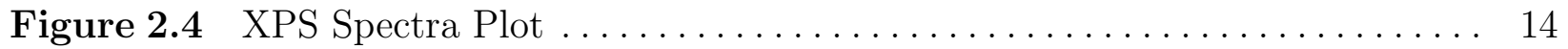

Figure $3.1 \quad$ Ternary Plots ...................................... 17

Figure 3.2 Density of State (DOS) Plots $\ldots \ldots \ldots \ldots \ldots \ldots \ldots \ldots \ldots \ldots \ldots \ldots \ldots \ldots \ldots \ldots$

Figure 3.3 Partial Density of State (PDOS) Plots ........................ 19

Figure 3.4 Integrated Local Density of State Plots........................ 22 


\section{LIST OF TABLES}

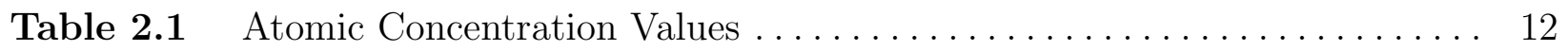

Table 3.1 Calculated and Experimental Values . . . . . . . . . . . . . . 16

Table A.1 MOFs as Catalyst . . . . . . . . . . . . . 32

Table A.2 Common Photocatalytic MOFs $\ldots \ldots \ldots \ldots \ldots \ldots \ldots \ldots \ldots \ldots \ldots \ldots$

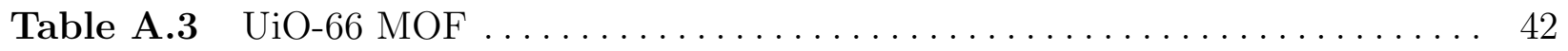

Table A.4 Replacement of $\mathrm{Zr} / \mathrm{BDC}$ in $\mathrm{UiO}-66 \mathrm{MOF} \ldots \ldots \ldots \ldots \ldots \ldots \ldots \ldots \ldots .48$

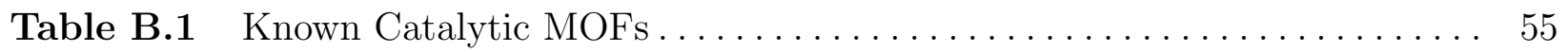

Table B.2 Reference Material $\ldots \ldots \ldots \ldots \ldots \ldots \ldots \ldots \ldots \ldots \ldots \ldots \ldots$ 


\section{CHAPTER 1}

\section{INTRODUCTION}

\subsection{Background of MOF}

MOF based materials have received considerable attention and achieved fast development due to their wide applications in gas adsorption $[1,2]$, storage [3], separation $[4,5,6,7]$, catalysis, sensing, molecular recognition, drug delivery, and more recently the application for photocatalysis. $[8,6]$ While the task of synthesizing a stable MOF proves difficult, the task of designing a MOF material that embodies several optimized material characteristics proves even more daunting. The attributes of interest for this research is centered around the application of the proposed MOF materials as a photocatalyst.[8, 6, 9] More specifically, this study has narrowed the focus to the influence of the inorganic portion of the MOF design on the light absorption properties of the MOF material. This study will use a combination of experimental and first principle computational techniques to explore the continuous design space of three inorganic substitutions in a UiO-66 MOF. The design space was limited to a UiO-66(M)-R, $\left[\mathrm{M}=\mathrm{Zr}\right.$, Ti, Hf; $\left.\mathrm{R}=\mathrm{BDC}, \mathrm{BDC}+\mathrm{NO}_{2}, \mathrm{BDC}+\mathrm{NH}_{2}\right]$ material system, which the Zr and Ti elements have been experimentally determined and the Hf was only computationally determined.

MOFs are functional inorganic-organic hybrid materials, are very interesting family of crystalline porous solids. They are constructed from inorganic metal ions and multiconnected organic bridging ligands to form infinitely uniform networked architectures in space.[10] MOFs have high surface area, tunable pore size, great chemical variation, with limited thermal stability. The objective in the development of a MOF based photocatalyst is to tailor several, often competing attributes. These attributes, which include high areal density of reaction sites, large utilization of the solar spectrum, and chemical selec- 
tivity are a few of the limiting attributes that required optimization. Compounding these multifaceted attributes with an nearly endless design space the task of optimizing a MOF structure becomes a daunting task. To aid in the design task the following study employs a computational first principle techniques in conjunction with experimental validation at key design points.

The zirconium and titanium based MOF (UiO-66(Zr) and $\mathrm{UiO}-66(\mathrm{Ti}))$ have been demonstrated previously in the literature $[11,12]$ in a diverse range of applications. This is attributed to higher thermo and chemical stability of the underlying framework, as well as electrically conductive compared to other types of MOFs. $[6,7,12]$ These MOF's have been extensively studied for the applications of photocatalysis, hydrogen generation, gas storage, drug delivery, etc.[6] However, solar energy utilization requires thermally stable[13] and electrically conductive[14] material. Furthermore, the proposed material must utilize as much of the visible region of the electromagnetic spectrum for efficient carrier ionization. By decreasing the band gap the electrons require less energy to overcome the band gap spanning from the LUMO to the HOMO. This is because the proposed MOF material is semiconductive in nature it is hypothesized that techniques used for inorganic substitution, such as substitutional doping, should also apply to MOF materials. That being said, the mechanism for modulating the band gap is also hypothesized to be different due to the inorganic-organic bonding inherit to these MOF materials. Understanding the importance of minimizing the band gap of the structure to achieve a more desirable result is what this study will investigate to a great extent.

The open structure of the MOF results in an increased surface area for unique uniaxial bonding of organic linkers, which provides an avenue to modulate the band structure. The MOF structure chosen for this study is based on the well established UiO-66(Zr) [11]. To tailor the band gap of the structure, most research approaches have modulate and modify the ligand coordination. This is a very effective way and has attained lots of attention in recent years. The most common and effective way to tailor the band gap is where ben- 
zenedicarboxylate (BDC) is modified with an amino group $\left(\mathrm{NH}_{2}\right)$ and a nitro group $\left(\mathrm{NO}_{2}\right)$ resulting with $\mathrm{UiO}-66(\mathrm{Zr})-\mathrm{R},\left[\mathrm{R}=\mathrm{H}, \mathrm{NH}_{2}, \mathrm{NO}_{2}\right] .[8,15,3,4]$ This study will explore similar techniques, however, will focus on substitution of the inorganic ions situated at the corners in the UiO-66 MOF. The approach will be to substitute Zr ions in the host MOF with a compatible ion with a similar oxidation state. Using the guidance of previous experimental synthesis this study will also explore every variation of $\mathrm{Zr}$, Ti, Hf elements in combination (substitutional doping of the structure) to explore all possible outcomes for the band gap. This study will implement the first principle density functional theory (DFT) predictions [16] that will be verified and validated with available experimental [17, 18, 19, 20] results and results synthesized for this study.

\subsection{Catalog of Common MOFs}

These MOFs have drawn considerable awareness because of the potential exploiting properties of both organic and inorganic components within a single material. As well as their modulating nature and synthesis conditions, these organic/inorganic molecules offer tunable properties based on shape, size, and functionality.[21, 22, 23] These common MOFs tend to have features that allow for the ability to target structures of particular typologies that tend to be appropriate in certain applications by using a molecular building block approach. This approach is a design strategy for the construction of solid materials. These material's metal ions, coordination clusters, and organic ligands are pre-designed to have very specific geometry and directionality upon coordination to assist as building blocks to target structures.[21]

The study of MOF is a field of research that has rapidly risen to in modern chemistry. This field has grown from the initial to the very influential reports toward advanced design strategies, structural appreciation, and topological analysis in which has depicted a range of interesting material properties. Thus combines together diverse scientific disciplines in conjunction with synthetic methodologies and structural analysis with the sole purpose of 
making new generations of MOFs. This research area has surpassed its original development in coordination and super molecular chemistry to embrace materials that deal in separational science, theory, electronics, magnetism, and catalysis.[21, 22] This is why this investigation aspires to catalog recognized work in this developing new field.

Extensive time was spent on classifying numerous research areas that depict MOFs in their investigations. This yielded over two-hundred different research publications that investigate MOFs to a great degree. This just shows how much attention MOFs have attained in the past few years due to its diverse applications. These various MOFs are classified in Appendix A of this study, which briefly depict the title of the publication, formula, and application of the researched MOFs. These publications are classified under MOF's as catalyst, common photocatalytic MOFs, and more related to this study the publications of UiO-66 MOF, and the replacement of Zr/BDC in UiO-66 MOF. These publications really assisted in understanding and figuring out the relevant data to be derived of this investigation.

The reader should note that most of these publications have been conducted within the past ten years. Although MOF based structures was proposed nearly 20 years ago [24] and experimentally demonstrated 15 years ago, only recently has there been extensive experimental exploration. The reason for the delay is due to the necessity of first developing a substantial foundation of MOF synthetic chemistry. [24] However, with significant amount of such chemistry in place, it has been possible for researchers in this area to envision a variety of strategies that can be evaluated experimentally in a quick manner. Along with diverse applications, MOFs have really gained more attention as catalytic material.

\subsection{Catalog of Known Catalytic MOFs}

Catalyst material (substance) are known to increase the rate of a chemical reaction. This is refereed to as catalysis in which a catalyst material will contribute to the chemical reaction. These reactions happens much faster and require less activation energy. One great aspect of catalytic materials are that they do not get absorbed or consumed in the chemical 
reaction. Meaning that the material can continue to catalyze the reaction of the reactant, and often small amount of the catalytic material is needed.

However, only a few dozen reports of chemical catalysis by MOF crystalline have appeared to date. In Appendix B Table B.1 are the majority of known cataloged MOF catalytic material taken from the publications in Appendix A Table A.1 (MOFs as Catalyst) as well as provided from the literature.[24, 25, 26, 27] Appendix B Table B.1 also depicts descriptions of the specific catalyzed reaction and what substrate was used for the MOF Material. References to each specific catalog of known catalytic MOF is given as well as reference materials to assist with identification of each chemical formula within Appendix B Table B.2.

One of the earliest proposed applications [28] and demonstration for crystalline MOF materials are as heterogeneous catalysis. These materials are porous and robust, and therefore well suited to catalysis under extreme conditions. This porosity yields internal surface areas that are relatively large which facilitates their catalytic reactivate. The uniformity of their pore and channel sizes accounts for much of the catalytic selectivity.[24] Although these relevant features are shared with other materials, however crystalline MOFs differ in other important ways. For instance, MOFs contain organic components, and MOFs can be synthesized in much greater chemical variety.[23] In addition, to good thermal stability, some MOFs demonstrate stability to substantially above $500^{\circ} \mathrm{C}[24,29]$ and many exhibit permanent microporosity. MOFs are superior in comparison to traditional catalysts because of their desirable topology and high surface area which allows for accommodation of guest molecules.

\subsection{Photocatalytic MOFs}

Additionally, the HOMO-LUMO gap can easily be tuned through modification of the inorganic or organic units of the molecule during its synthesis. Thus, efficient visible light harvesting can be achieved using MOFs. They consist of a microporous structure which 
has a surface area exceeding traditional porous materials such as zeolites and carbons.[30] Additionally, their pore volume values are associated among the highest reported for any material. This porousness is due to the presence of the strong metal ligand interactions which allow for removal of a solvent molecule without structural collapse of the framework. The influential features of MOFs such as pore size, shape, and chemical environment can be finely tuned by the selection of the metal and ligand building blocks of the MOF.

These MOFs act as a molecular filter, by which molecules can diffuse through its pores. Another means of interaction is that of guest molecule with transition states for the reactions formed within the scope of the pores. Synthesizing MOFs is usually performed by adding the molecular building blocks into solutions or through solvothermal procedures. This possibility for modifying the organic ligands and consequently the pore size and shape allows tailoring the MOF material to suit the needs of various applications. In Appendix A Table A.2 common photocatalytic MOFs are cataloged and expressed with the appropriate application for each specific MOF. 


\section{CHAPTER 2}

\section{COMPUTATIONAL AND EXPERIMENTAL DETAILS}

\subsection{Material Design}

The material of interest (UiO-66(M)-BDC) has experimentally demonstrated excellent thermal and chemical stability for which can be implemented for various applications.[15, 12, 31] The objective of the study is to investigate how the UiO-66 structure can be modified to allow better conditions for light absorption. More specifically, the objective will be to understand how the inorganic portion can contributes to the modulation of the band gap.

The main structural modification was substitution of the inorganic ion with all possible positions in the unit cell (UiO-66(M)-BDC, M = Ti, Zr, Hf). The MOF structure has inorganic elements at the outer corners and a single length linker (UiO-66). The conventional unit cell has 456-atoms and at the body centered position is a pore; however, to reduce the computational strain, a primitive unit cell consisting of 114-atoms is used for this study (Figure 2.1). The six inorganic positions are clearly illustrated in Figure 2.1 of the primitive unit cell. Also, the functionalized groups that consisted of amino group $\left(\mathrm{NH}_{2}\right)$ and the nitro group $\left(\mathrm{NO}_{2}\right)$ design is illustrated in Figure 2.1. Part a of Figure 2.1 illustrates the original linker design, part b is the structure with the replacement of one hydrogen atom on the linkers aromatic ring with a nitro group $\left(\mathrm{NO}_{2}\right)$, and part $\mathrm{c}$ is the replacement of one hydrogen atom with an amino group $\left(\mathrm{NH}_{2}\right)$.

Every configuration combination of the three inorganic elements (Zr, Hf, Ti) were calculated in the six positions within the primitive unit cell. Because there are six positions

for ion substitution there is a series of sub-cases that must be considered to account for all possible coordination of the substitutional species. For example, if four of the six position are filled with Zr and the remaining two are filled with Ti. The question arises which 


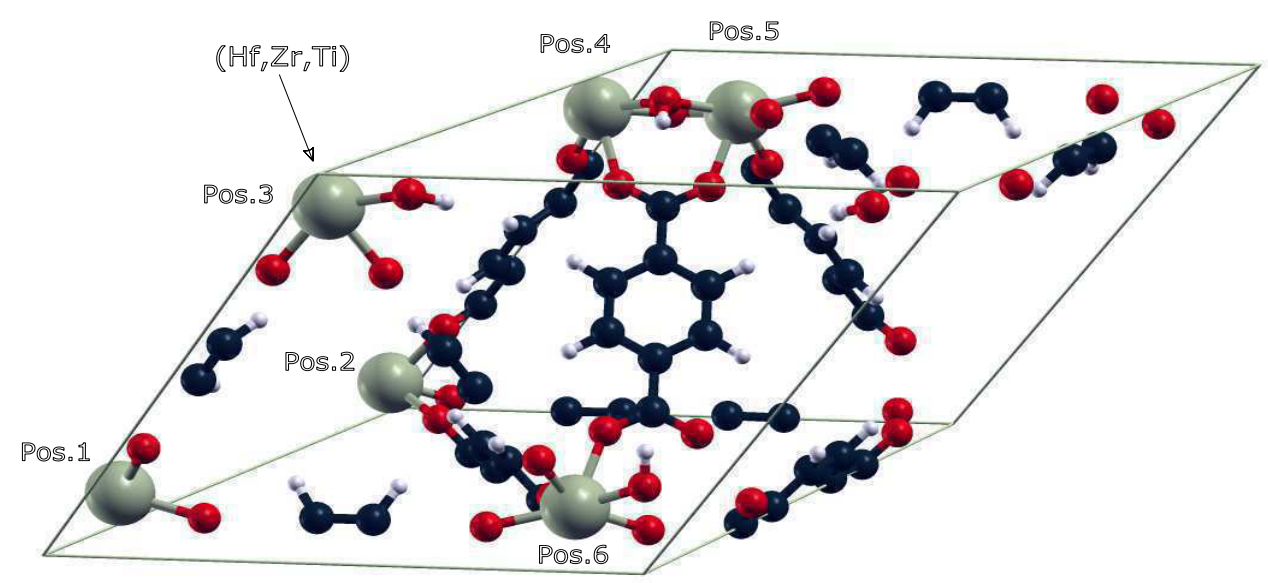

a)

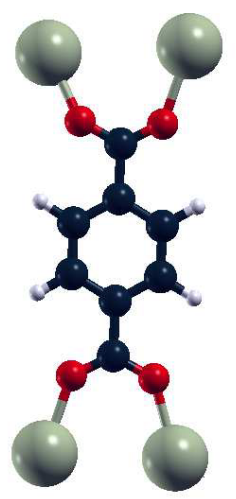

b)

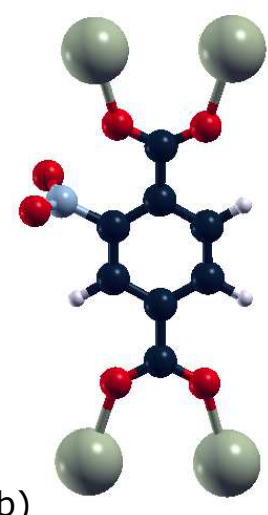

c)

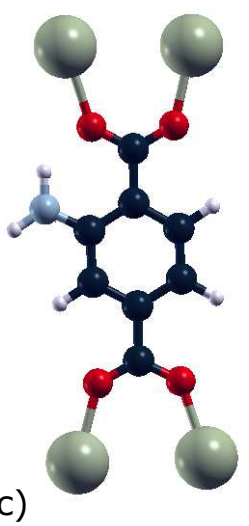

Figure 2.1 Top figure illustrates the primitive unit cell of $\mathrm{UiO}-66(\mathrm{M}),(\mathrm{M}=\mathrm{Ti}, \mathrm{Zr}, \mathrm{Hf})$. Shows the 114-atom primitive unit cell. The six positions that were modified are depicted in the figure and in the center of the cell the linker design is clearly shown. The unit cell is made of inorganic (gray), carbon (dark blue), oxygen (red), hydrogen (white), and nitrogen (light blue). The bottom figure shows the unit cell of the three linker design. Part (a) is $\mathrm{UiO}-66(\mathrm{M})$, part (b) is $\mathrm{UiO}-66(\mathrm{M})-\mathrm{NO}_{2}$, and part (c) is $\mathrm{UiO}-66(\mathrm{M})-\mathrm{NH}_{2}$.

two positions within the unit cell should the two Ti occupy. This defines the sub-case for each configuration and for this study the two ions were simulated at every possible combination and the total energy was determined. The sub-case configuration with the lowest configuration was taken as the most favorable configuration. There is a total of 729 trials that had to be executed and analyzed just for one of the three functionalization cases. Once the data was analyzed for the BDC, only the best (lowest gap size) was functionalized for each case and that consisted of 28 trials for the $\mathrm{BDC}-\mathrm{NO}_{2}$ and 28 trials for $\mathrm{BCD}-\mathrm{NH}_{2}$. 
Also, each trail had various operations that had to be done in sequence to obtain proper data. The reader should note that this is a tremendous amount of computational and analytically challenging process. Typically each trial took approximately 30 hours of computational time, it is noted that 12 trails could be run at a given time due to the allocated time for this project. This is an area that needs to be developed from a statistical point of view to decrease the computational expense for larger design spaces.

\subsection{Computational Details}

A density functional theory (DFT) approach [16] was implemented to predict the ground state thermodynamic properties (lowest posible energy level) for each of the thermodynamic steps. To reduce the computational expense of the simulations, only a single primitive cell was simulated for each configuration. In addition, a pseudodized wave function approach was used to reduced the computational expense. The functional form of the pseudowave functions were based on Perdew-Burke-Ernzerhof (PBE) ultrasoft potentials with a cut-off wave function energy of $680 \mathrm{eV}$ (50 Ry). Several other functionals such as BLYP and their hybrid counter parts were investigated but the PBE was found to be most accurate and stable for the given unit cell. The k-point mesh was sampled using a Monkhorst Pack $4 \times 4 \times 4$ grid with a offset of $1 / 4,1 / 4,1 / 4$. To account for the Van der Waals interaction a Van der Waals correction term $[32,33]$ was incorporated, which introduced some empiricism into the calculation. The scaling parameter (S6) were specified to be 0.75 and cut-off radius for the dispersion interaction was 200 angstroms. Both the ion and unit cell geometries were relaxed to a relative total energy less than $1 \times 10^{-10}$ and overall cell pressure of less than 0.5kBar. The reader should be made aware that pure DFT predictions of band gap are often under predicted due to the over-analyticity of the functionals and exchange-correlation terms. Therefore, the band gaps reported in this study should not be used as absolutes but used to study the trends. 


\subsection{Experimental Details}

Synthesis UiO-66(Zr) MOFs with different side functional groups $\mathrm{H}, \mathrm{NO}_{2}$ and $\mathrm{NH}_{2}$ were synthesized according to previous paper [11] with a solvothermal method. Synthesis of the UiO-66(Ti- $\mathrm{Zr})-\mathrm{R}\left(\mathrm{R}=\mathrm{H}, \mathrm{NO}_{2}\right.$, and $\left.\mathrm{NH}_{2}\right)$ follows the procedure found in the literature [18]. The UiO-66(Ti-Zr)-NH $\mathrm{NH}_{2}$ MOFs were synthesized via a post-exchange method according to the literature [34]. The UV-Vis absorption spectra for all materials were acquired on a Shimadzu 2550 UV-VIS spectrometer under the diffuse-reflection model using an integrating sphere. X-ray photoelectron spectroscopy (XPS) was recorded to determine the chemical status of elements on a PHI 5000 Versa Probe system. The corresponding UV-Vis spectrum for all of the samples synthesized is found in Figure 2.2 and the corresponding band gap values are found in Table 3.1.

\subsubsection{Experimental Synthesis}

The UiO-66(Zr) MOFs with different side functional groups $\mathrm{H}, \mathrm{NO}_{2}$ and $\mathrm{NH}_{2}$ were synthesized according to previous paper with a solvothermal method [11] The UiO-66(Ti,Zr)NH2 MOFs were synthesized via a post-exchange method according to the literature [34]. Asprepared $\mathrm{UiO}-66(\mathrm{Zr})-\mathrm{NH}_{2}$ was dispersed in toluene under $\mathrm{N} 2$ flow, then appropriate amount of Titanium butoxide was added to yield different Ti substitution ratios. The mixture was stirred at $100 \mathrm{C}$ under $\mathrm{N}_{2}$ protection for different time intervals. The final product was collected with centrifuge and washed with toluene for multiple times, and dried under vacuum at $120 \mathrm{C}$.

The four atomic concentrations for the titanium substitution are provided in Table 2.1. Notice that on the fourth trial all of the inorganic ions were substituted except one results in a $\operatorname{Ti}_{5} \mathrm{Zr}_{1}$. The inability to fully substitute $\mathrm{Ti}$ on the lattice is a result of the experimental techniques and the binding energy of the final Ti ion. However, the fully substituted Ti can be synthesized based on the theoretical calculation, which predict a stable configuration. 


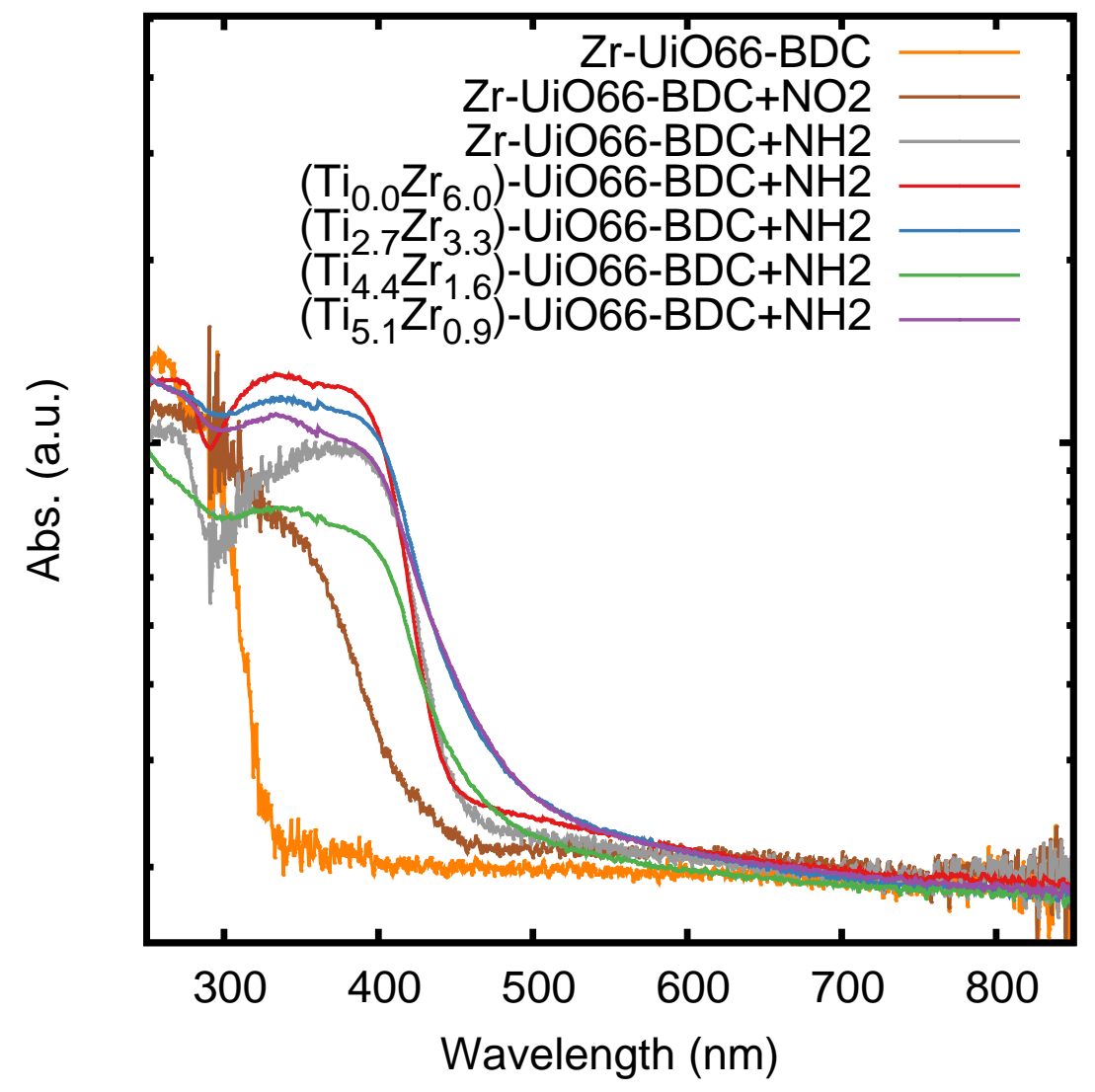

Figure 2.2 Plot of the experimental UV-Vis spectrum for UiO-66(Zr)and UiO-66(Zr, Ti)-R $\left(\mathrm{R}=\mathrm{H}, \mathrm{NO}_{2}\right.$, and $\left.\mathrm{NH}_{2}\right)$. The fraction of $\mathrm{Ti}_{x} \mathrm{Zr}_{x-1}$ correspond to the six ion positions available in a single primitive. Complete experimental substitution of Ti was not experimentally demonstrated (only five of the six position on the primitive cell were substituted) but theoretically calculated, this suggest that full substitution should be possible. The corresponding experimental band gap values can be found in Table 3.1. 
Table 2.1 Atomic concentrations of $\mathrm{Ti}$ and $\mathrm{Zr}$ in four representative samples for the UiO$66\left(\mathrm{Ti}_{x} \mathrm{Zr}_{1-x}\right)-\mathrm{NH}_{2}$. The last two columns correspond to the number of inorganic position fill in the primitive unit cell, which had six positions. Note, the fourth trial did not reach full substitution due to experimental limitations.

\begin{tabular}{cccccc}
\hline Trial & Ti Concentration & Zr Concentration & $\mathrm{Ti} / \mathrm{Zr}$ & $\eta_{Z n}$ & $\eta_{T i}$ \\
\hline 1 & 0 & - & 0 & 6.00 & 0.00 \\
2 & 3.37 & 4.01 & 0.84 & 3.26 & 2.74 \\
3 & 8.41 & 2.99 & 2.81 & 1.57 & 4.42 \\
4 & 11.63 & 1.95 & 5.96 & 0.86 & 5.14 \\
\hline
\end{tabular}

The UV-Vis absorption spectra for all materials were acquired on a Shimadzu 2550 UV-VIS spectrometer under the diffuse-reflection model using an integrating sphere. The $\mathrm{UV}-\mathrm{V}$ is for all samples can be found in the main article and the UV-Vis for the four Ti exchange trials that correspond to Table 2.1 can be found in Figure 2.3.

After the Ti-Zr exchange, clear Ti2p peaks were detected with XPS for all samples, as shown in Figure 2.4. As demonstrated in paper [34], Ti has been successfully partially substituted $\mathrm{Zr}$ in UiO-66- $\mathrm{NH}_{2}$. The substitution ratio was dependent on the Ti precursor concentration and the exchange time period. 


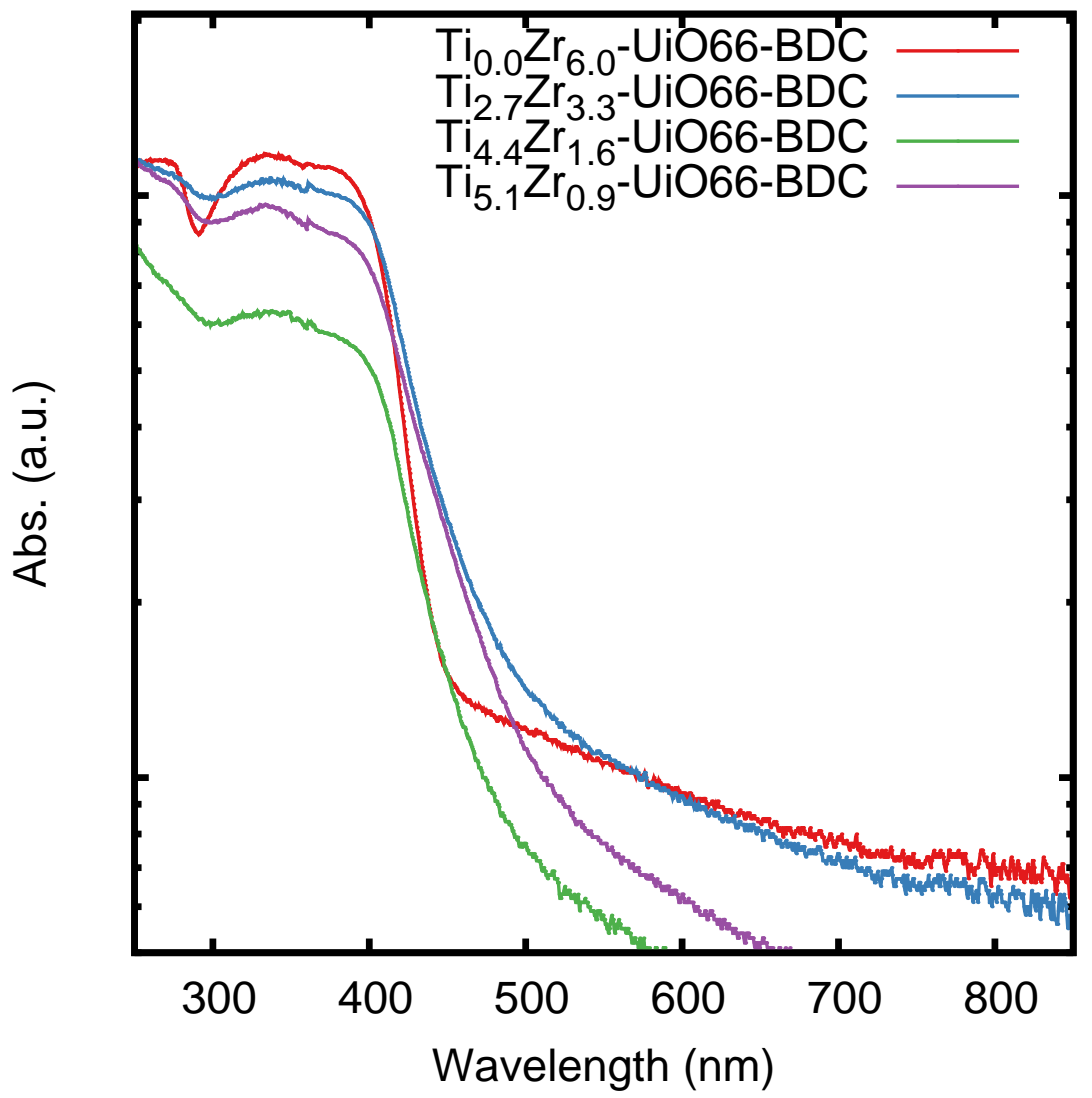

Figure 2.3 Plot of the UV-Vis for four different Ti exchanges on the UiO-66(Zr) lattice. This plot corresponds to Table 2.1. 


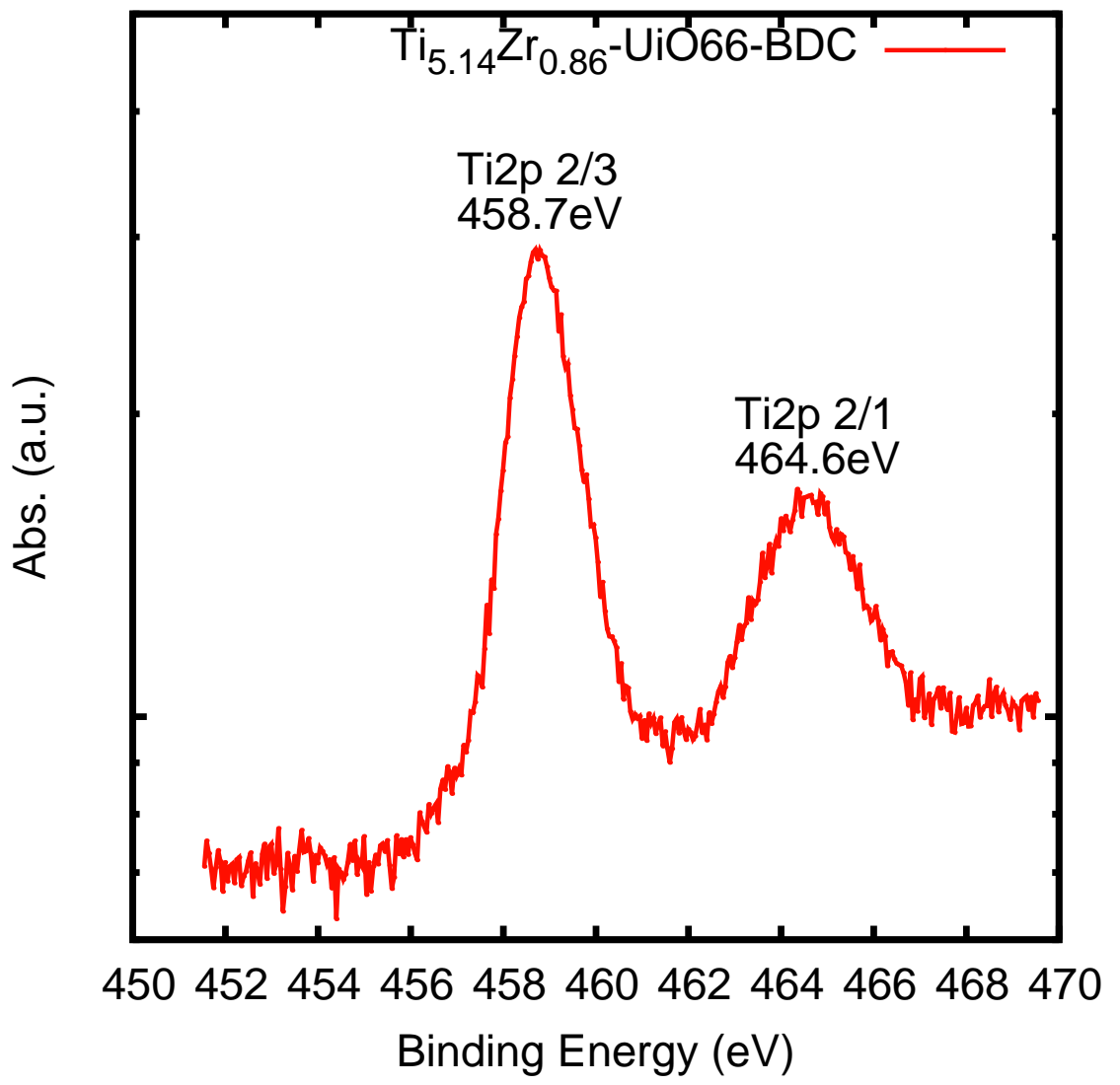

Figure 2.4 Plot of the XPS spectra for Ti2p after Ti-Zr exchange. 


\section{CHAPTER 3}

\section{RESULTS AND DISCUSSION}

\subsection{Results and Discussion}

The substitutional exchange of the inorganic ions was carried out for a single unit cell by substituting the inorganic ion for one of three ions, which include Zr, Hf, Ti. The band gaps were then predicted using DFT calculation and compared to experimental values at the end point of the design space. It has been confirmed in previous studies [15] that this particular metal-organic (UiO-66) structure exhibits semiconductor type band gaps. This is reasoned based on the moderate band gap size and the electron charge transfer behavior. Under this assumption it is accepted that this particular structure should be able to be subsitutionally doped. However, it is uncertain how the substitutional doping will manifest itself in modulation of the band structure. It has been well demonstrated that functionalization of the organic linkers provides a profound influence on the band gap by introducing mid gap states. Using the aid of DFT predictions in conjunction with validation with experimental findings the following discussion will elaborate on the exchange of the inorganic ion on the modulation of the band gap.

A summary of the band gap prediction can be found in Figure 3.1, which illustrates the band gap modulation for three inorganic ions and three functionalizations. In all three

of the functionalization cases the smallest band gap was realized for a titanium inorganic ion. It is noted though comparison of the contours across each of the ternary plots of Figure 3.1 that the modulation trends are not consistent for each functionalization case (note the independent contours). The most noticeable deviation out of all three ternary is the BDC functionalization case. Here this incorporation of Zr results in slight increase of $0.2 \mathrm{eV}$ over the pure $\mathrm{Hf}$ case. This is not the case for the other two functionalization 
Table 3.1 Calculated and experimentally determined band gap energies for the three MOF linker designs and three functionalizations. The DFT values in parentheses are the band gap energies ignoring a mid-gap impurity band. The experimental data was determined using UV-Vis spectrometer, see Figure 2.2. The asterisk $\left(^{*}\right)$ next to the experimental values denotes only partial substitution of $\mathrm{Ti}$ on the $\mathrm{Zr}$ host sites, $\mathrm{Ti}_{5} \mathrm{Zr}_{1}$.

\begin{tabular}{lcc}
\hline Design & DFT (eV) & Experimental UV-Vis (eV) \\
\hline Zr-BDC & $2.96(3.15)$ & 3.76 \\
Zr-BDC+NO2 & $2.62(3.19)$ & 2.93 \\
Zr-BDC+NH & $1.94(3.10)$ & 2.75 \\
Ti-BDC & $2.67(2.80)$ & - \\
$\mathrm{Ti}-\mathrm{BDC}+\mathrm{NO}_{2}$ & $2.35(2.87)$ & - \\
$\mathrm{Ti}-\mathrm{BDC}+\mathrm{NH}_{2}$ & $1.62(2.77)$ & $2.60^{*}$ \\
$\mathrm{Hf}-\mathrm{BDC}$ & $2.74(3.11)$ & - \\
$\mathrm{Hf}-\mathrm{BDC}+\mathrm{NO}_{2}$ & $2.66(3.17)$ & - \\
$\mathrm{Hf}-\mathrm{BDC}+\mathrm{NH}_{2}$ & $1.98(2.96)$ & - \\
\hline
\end{tabular}

where the fully doped Hf case results in the largest band gap. This provides an overview of the very essence of this study and this is evident that the inorganic portion of the MOF is changing the charge state of aromatic ring or light sensitive portion of the MOF structure. Fortunately, through the use of DFT modeling it is possible to ascertain information about the nature of the inorganic ion that is not readily available from a pure experimental point of view.

To better understand how the band gap energy is modulated for different configurations, the density of states (DOS) allows visual inspection of the number of states as a function of energy level. Figure 3.2 are plots of the DOS along the outer edge of each ternary plot. These surface plots of the total density of states permit the inspection of each state as different inorganic ions are substitutionally doped into the structure. Note, these are DFT predictions of the band gap energies and the band gap is typically under predicted with DFT modeling, however, the relative comparison of the band gap energy is still permitted. As can be seen in Figure 3.2, Ti proves to have the lowest overall band gap. It is evident that the Ti has a strong influence on the valance band edge and subsequently the band gap 


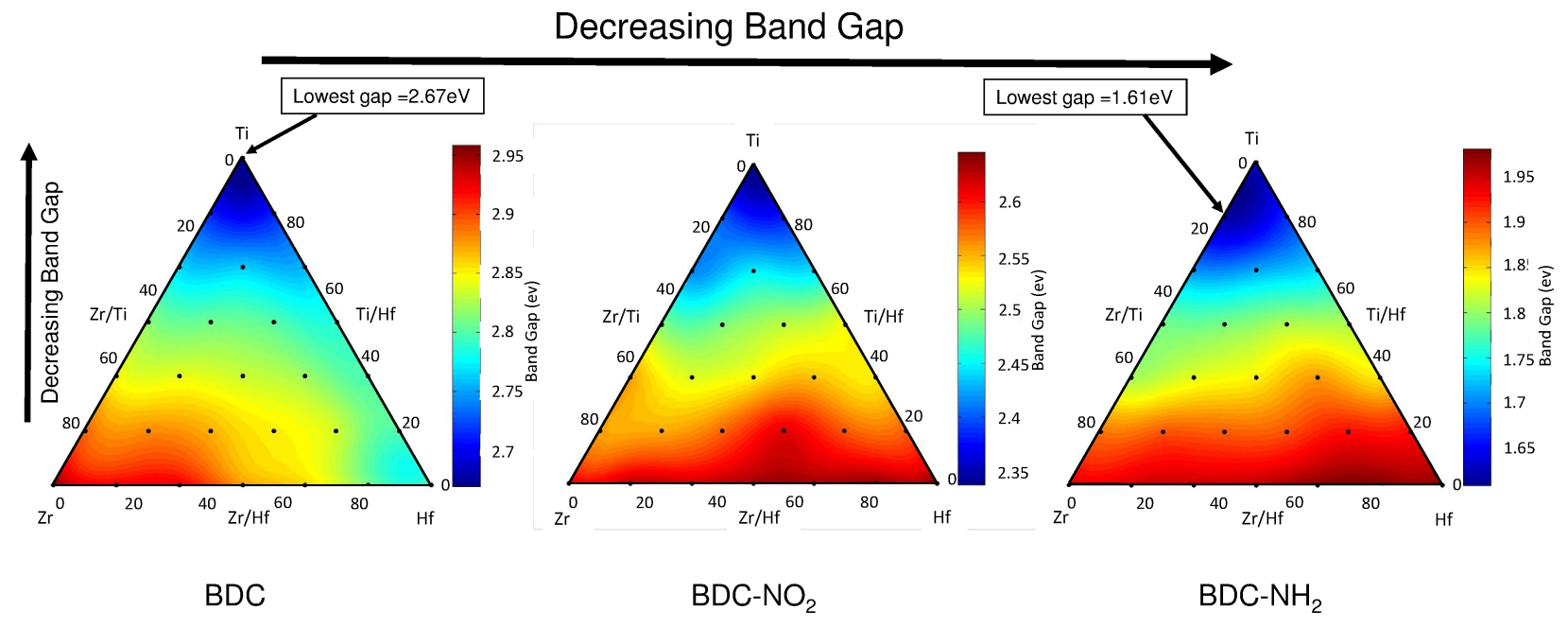

Figure 3.1 Illustration of three ternary plots for all possible combinations of the three inorganic elements ( $\mathrm{Zr}, \mathrm{Ti}, \mathrm{Hf}$ ) for three functionalizations (BDC-R, $\left[\mathrm{R}=\mathrm{H}, \mathrm{NO}_{2}, \mathrm{NH}_{2}\right]$ ). The contour colors of each ternary plot corresponds to the predicted band gap, which was determined from the DFT predictions. The implemented Ti structures proved to have the lowest band gap for all three functionalizations. A UiO-66(Ti)- $\mathrm{NH}_{2}$ proved to have the lowest band gap with a corresponding value of $1.61 \mathrm{eV}$ considering a impurity band. Experimental values were determined a the corners and are provided in Table 3.1. Note, these band gaps are known to be under predicted when compared to experimental values due to inherent approximations of DFT.

(Fermi energy across all configurations has been aligned in Figure 3.2). One aspect that is noted when comparing across the three functionalization is the mid-gap states, which are a result of the functionalization. It is noted that the $\mathrm{NH}_{2}$ results in a significant mid-gap state. More interesting, for the $\mathrm{NO}_{2}$ functionalized case there is a mid-gap state introduced near the valance band edge, which is shifted in the positive energy direction for the Ti case. Again this provide some evidence that the $\mathrm{Ti}$ ions are influencing the charge states of the aromatic carbon, which the functionalization are bonded.

Figure 3.3 are the molecular density of states for the all of the functionalizations cases at the end points of the design space. It becomes apparent from Figure 3.3 which molecular orbitals contribute to the total band gap energy, the lines designated by total is the total density of states (as provided in Figure 3.2). Figure 3.3 permits considerable insight of the molecular orbital states that is not readily accessible from a pure experimental point of view. Figure 3.3a-c correspond to the three different functionalizations. In Figure 3.3a and the 


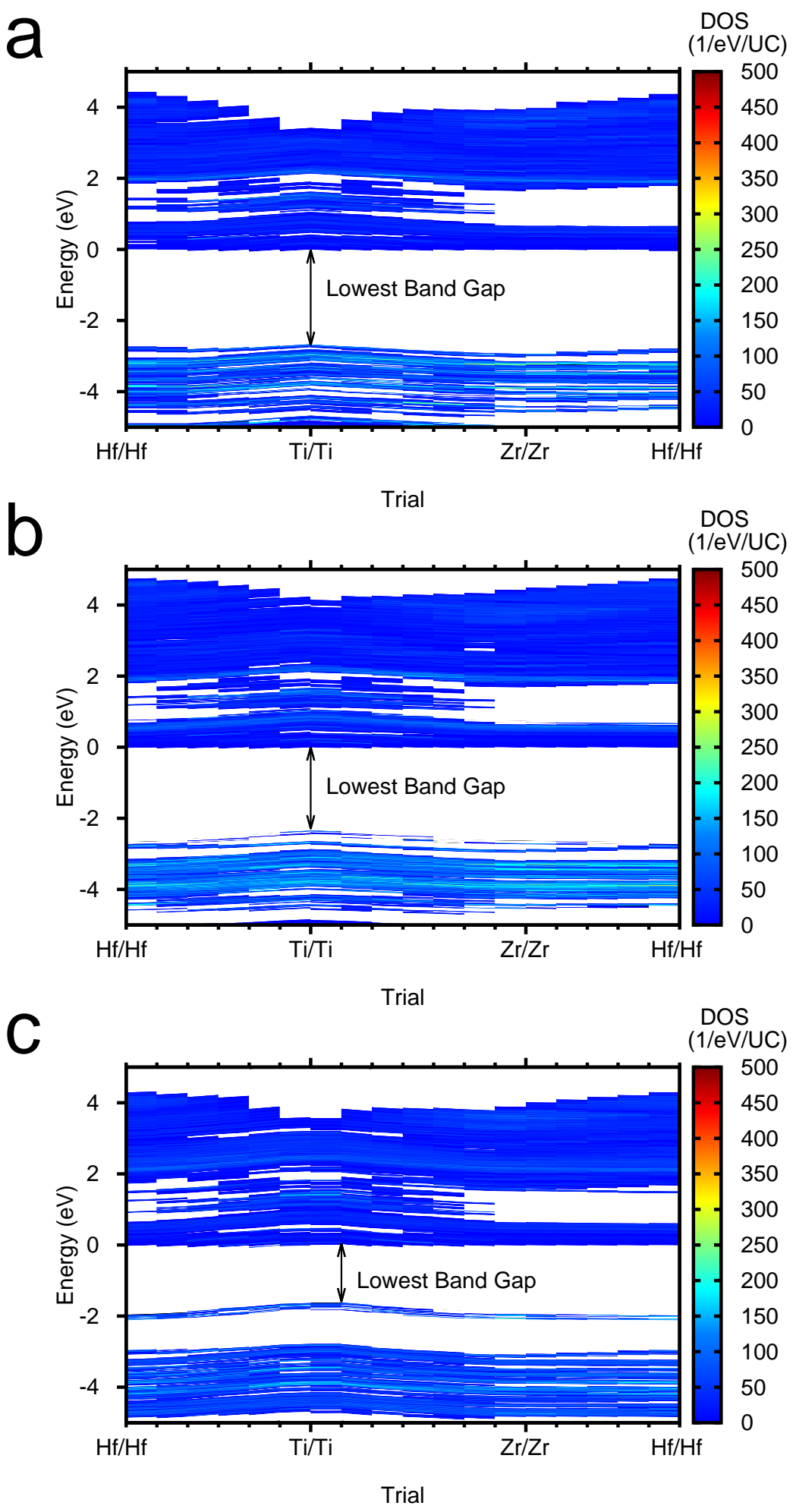

Figure 3.2 Plot of the density of states (DOS) along outer edge of composition along the ternary plot provided in Figure 3.1. Part a is UiO-66(M), Part b is UiO-66(M)- $\mathrm{NO}_{2}$, and Part c is UiO-66(M)- $\mathrm{NH}_{2}$. The Fermi energy is aligned for each of the figures. The lowest band gap is associated with titanium inorganic ion, $\mathrm{UiO}-66(\mathrm{Ti})-\mathrm{R}$. The inorganic ion significantly modulates the HOMO, which is associated with the p-orbitals of the aromatic carbon atoms. 

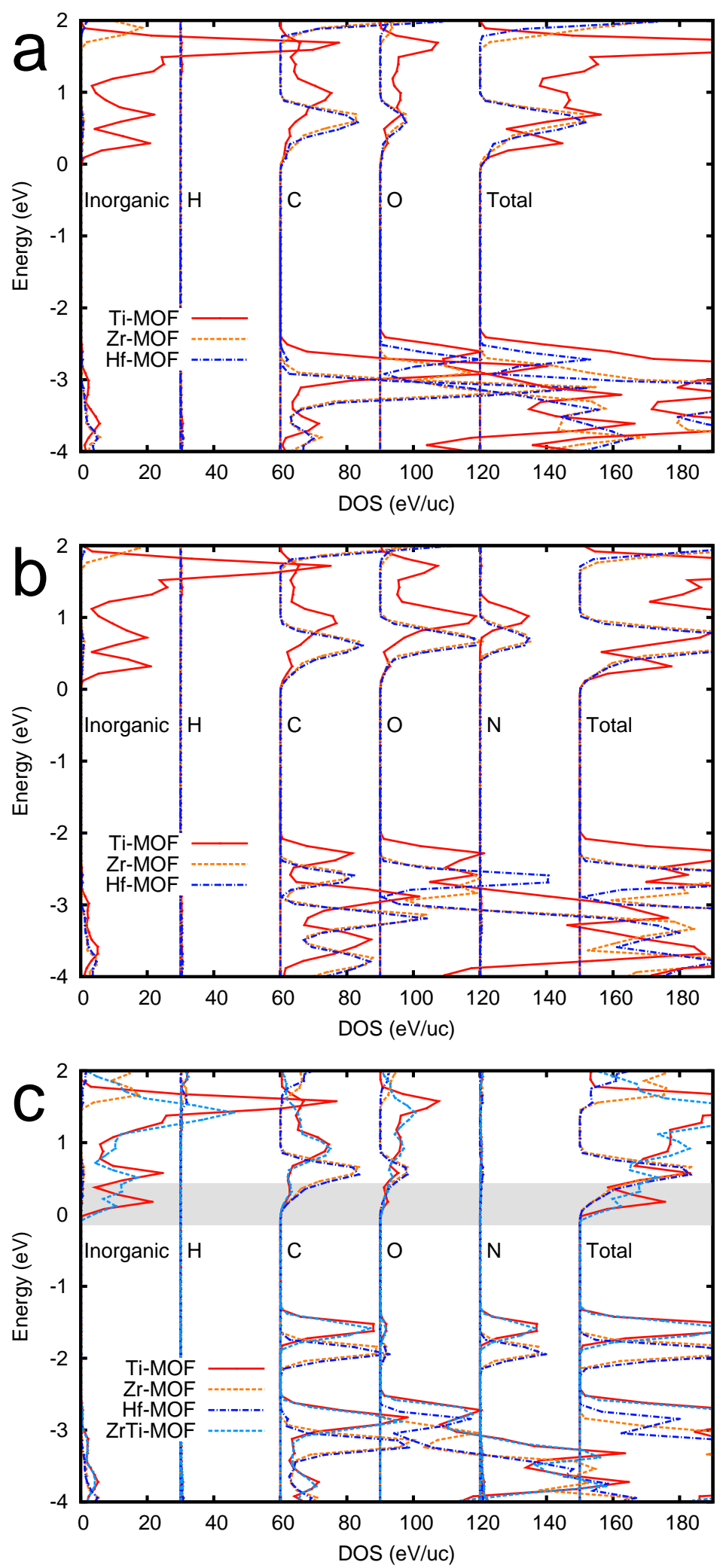

Figure 3.3 Plot of the partial density of states (PDOS) of the molecular orbitals for the three MOF designs. Part a is UiO-66(M), part b is UiO-66(M)-NO ${ }_{2}$, and part c is UiO$66(\mathrm{M})-\mathrm{NH}_{2}$. The Ti ion modifies the C-O pi-pi bond state, which results in modulation of the $\mathrm{HOMO} \mathrm{C}$ and $\mathrm{O}$ states. 
Ti case, the HOMO level is attributed to the $\mathrm{Ti}$ ion (inorganic) orbitals. There is also a noticeable modification of the oxygen and carbon states, in the case of Ti. This behavior confirms that the $\mathrm{Ti}$ is modifying the oxygen and aromatic carbon states and ultimately the band gap. However, based on the total density of states, it is the HOMO that is undergoing the most modulation as a result of of the inorganic substitution. In Figure 3.3a for the $\mathrm{Ti}$ case there is a considerable modulation of the HOMO oxygen and carbon states. This is apparent in all three functionalization cases, Figure 3.3a-c.

The inorganic ion (Ti, Hf, Zr) within the structure is bound by an oxygen and then to the aromatic carbon, as seen in Figure 2.1. The binding of the titanium with oxygen is a more complicated interaction when compared to $\mathrm{Hf}$ and $\mathrm{Zr}$ because of the hybridization bonding of Ti with oxygen. The binding with Ti-O is greater than the binding between Hf-O and $\mathrm{Zr}-\mathrm{O}$ as illustrated in Figure 3.4 with decreased bond length. This is to be expected as a result of lower atomic number of Ti. However, this increased binding leads to a change in the state nearest the HOMO level as shown in Figure 3.3. The $\mathrm{sp}^{3} \mathrm{~d}$ hybrid bonding(evident from the directional bonding) of titanium with oxygen is reasoned to be the indirect influence of the photosensitive aromatic carbon resulting in modulation of the band gap. Similar bonding interactions are evident in simple inorganic configuration of titanium oxides. However, in this case the Ti-O, bonds acts to influence a neighboring binding of the organic linker. More specifically, the Ti-O cluster act like the sp2 pi-pi binding of aromatic carbon and can be visually confirmed through inspection of the local density of states (Figure 3.4). The pi-pi electron clouds are slightly distorted by the Ti-O cluster, confirming a change in the charge state of the photosensitive aromatic carbon. This similar influence is also induced by the functional groups that bond with the pi orbitals of the aromatic ring, which also induce a band gap modulation. Similar agreement can be found in the literature [35]. Interestingly, the functional induced band modulation depends on the nature of the functional group and the type of functional group and not on the number of functional groups on the linker. The linker's pi orbitals contribute to the top levels of the HOMO, however, functional groups 
seem to have no effect to the LUMO [35].

The functionalized cases play a critical role in contributing to the band gap modulation. In the UiO-66(Zr)-BDC structure, upon Ti substitution and subsequent functionalization there is further modulation of the band gap. A visual confirmation of the change in local density for the three inorganic substitutions are depicted in Figure 3.4 for the amino functionalization. This density plots corresponds to the grayed region of the partial density of states plot, Figure 3.3c. At first glance the density distribution for the three structures look similar, however, after close inspection of the inorganic ions, it is apparent that $\mathrm{Ti}$ has an influence on the HOMO level. As shown in Figure 3.4 the ion distance between the inorganic ion and the oxygen results in an in-direct influence to the photosensitive aromatic carbon. The $\mathrm{Zr}$ has the larger distance followed by $\mathrm{Hf}$ and $\mathrm{Ti}$, which is a similar trend to the band gap with Ti having the lowest.

A summary of the predicted DFT and the experimental band gap values are provided in Table 3.1. The predicted band gaps in this study are corroborable with other studies $[8,7$, $9,15]$ and the experimental values conducted in this study. The lowest band gap was UiO$66(\mathrm{Ti})-\mathrm{NH}_{2}$. This is a results of both a mid gap state as a results of the functionalization and modulation of the HOMO level as a results of the Ti-O-C interaction. While, the full exchange of $\mathrm{Ti}$ within $\mathrm{UiO}-66(\mathrm{Zr})$ was not feasible experimentally there is reason to belive a fully exchanged UiO-66(Ti) should be able to be synthesized based on stability of structure from a theoretical point of view. However, the post-exchange method demonstrated in this study demonstrates the possibility to apply this method to other stable MOF design to further modulate their optical properties. 

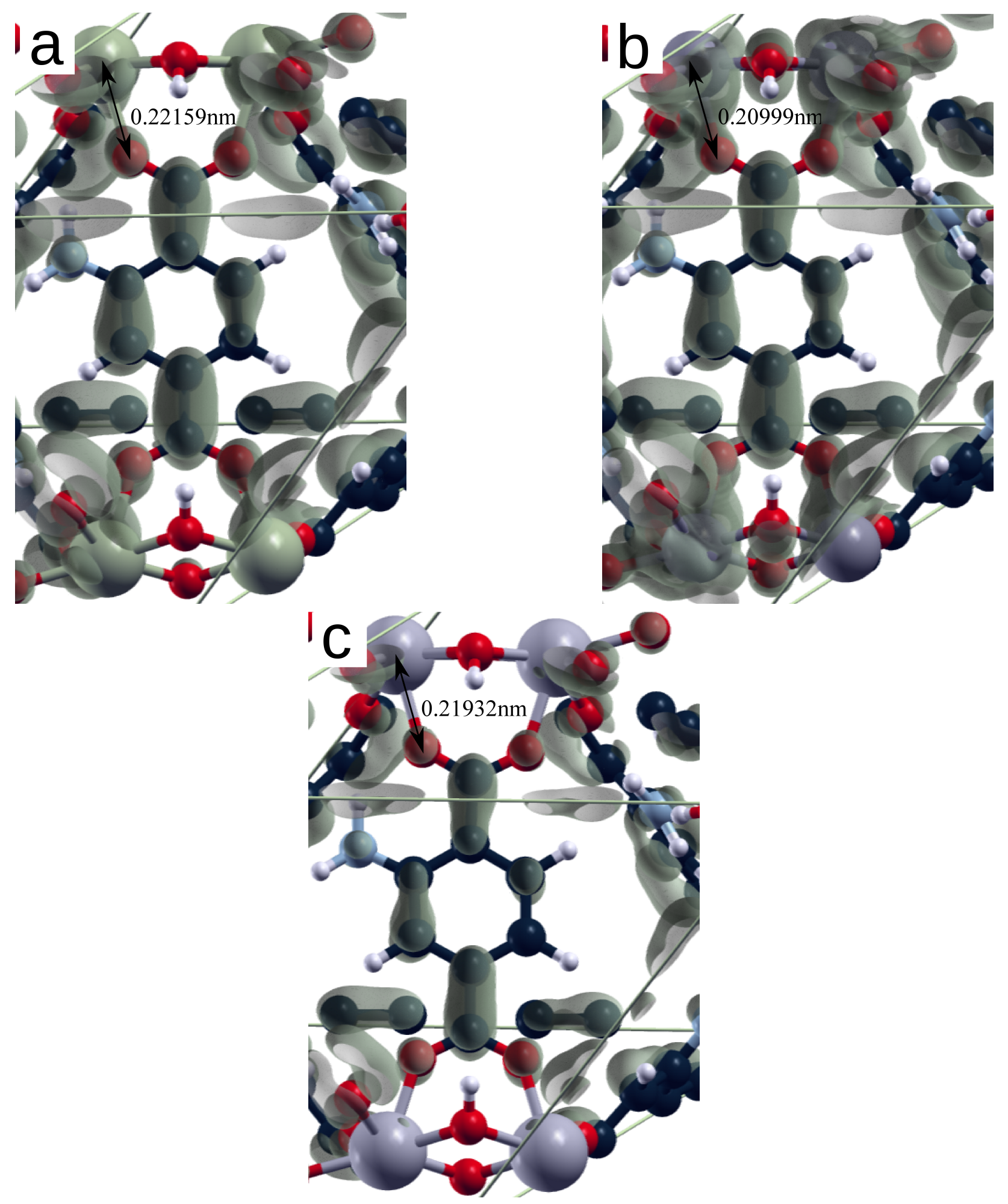

Figure 3.4 Plot of the integrated local density of state for $\mathrm{UiO}-66(\mathrm{M})-\mathrm{NH}_{2}[\mathrm{M}=\mathrm{Hf}, \mathrm{Zr}$, Ti]. Top figure a illustrates Zr unit cell, b illustrates Ti unit cell, and c illustrates Hf unit cell. These figures shown correspond to the grayed region in Figure 3.3c . The Ti substitution is associated with decreased bond length between $\mathrm{Ti}-\mathrm{O}$ and associated decrease in the band gap. 


\section{CHAPTER 4}

\section{CONCLUSION}

This thesis catalogs common MOF designs based on application and diversity in various fields, as well as conduct an in-depth study of a UiO-66(M) [M = Ti, Zr, Hf] MOF structure with three linker designs of BDC, BDC-NO 2 , and BDC-NH$H_{2}$. There appeared trends in the catalog of certain MOF materials for certain applications. For instance, cataloged UiO-66 and MIL structured MOFs appeared more commonly in catalyst and photocatalytic applications due to their high porosity. The in-depth study of MOF structure was analyzed from a computational and experimental perspective, DFT calculations confirmed a reduction of band gap with increased exchange of inorganic Zr ion with a Ti. The resulting band gap size, which was smallest for the fully substituted Ti-BDC- $\mathrm{NH}_{2}$ functionalized yielding a band gap of $1.62(2.77) \mathrm{eV}$. The decrease in band gap was reasoned to be a result of the increased deformation of Ti-O bonding resulting in a modulation of the aromatic carbon O-C binding and ultimately a modulation of the band gap. The amino functionalization proved to introduce a mid gap state the band that further reduced the band gap. While experi-

mental synthesis only resulted in partial exchange of Zr and Ti (approximate experimental structure UiO-66 $\left.\left(\mathrm{Ti}_{5} \mathrm{Zr}_{1}\right)-\mathrm{NH}_{2}\right)$ the theoretical results suggest that full substitution should result in a stable structure. Furthermore, the experimental ion exchange method employed in this study has potential in other MOF structures for further band gap modulation through inorganic ion exchange. 


\section{BIBLIOGRAPHY}

[1] Wu Hui, Chua Yong Shen, Krungleviciute Vaiva, Tyagi Madhusudan, Chen Ping, Yildirim Taner, and Zhou Wei. Unusual and highly tunable missing-linker defects in zirconium metal-organic framework uio-66 and their important effects on gas adsorption. Journal of the American Chemical Society, 135(28):10525-10532, 2013.

[2] Yang Qingyuan, Wiersum Andrew D., Llewellyn Philip L., Guillerm Vincent, Serre Christian, and Maurin Guillaume. Functionalizing porous zirconium terephthalate uio-66(zr) for natural gas upgrading: a computational exploration. Chem. Commun., 47:9603-9605, 2011.

[3] Chi-Kai Lin, Dan Zhao, Wen-Yang Gao, Zhenzhen Yang, Jingyun Ye, Tao Xu, Qingfeng Ge, Shengqian Ma, and Di-Jia Liu. Tunability of band gaps in metal-organic frameworks. Inorganic Chemistry, 51(16):9039-9044, 2012.

[4] Pieremanuele Canepa, Nour Nijem, Yves J. Chabal, and T. Thonhauser. Diffusion of small molecules in metal organic framework materials. Phys. Rev. Lett., 110:026102, Jan 2013.

[5] Kui Tan, Pieremanuele Canepa, Qihan Gong, Jian Liu, Daniel H. Johnson, Allison Dyevoich, Praveen K. Thallapally, Timo Thonhauser, Jing Li, and Yves J. Chabal. Mechanism of preferential adsorption of so2 into two microporous paddle wheel frameworks m(bdc)(ted)0.5. Chemistry of Materials, 25(23):4653-4662, 2013.

[6] Lijuan Shen, Ruowen Liang, Mingbu Luo, Fenfen Jing, and Ling Wu. Electronic effects of ligand substitution on metal-organic framework photocatalysts: the case study of uio-66. Phys. Chem. Chem. Phys., 17:117-121, 2015.

[7] Sibo Wang and Xinchen Wang. Multifunctional metalorganic frameworks for photocatalysis. Small, 11(26):3097-3112, 2015. 
[8] Li-Ming Yang, Eric Ganz, Stian Svelle, and Mats Tilset. Computational exploration of newly synthesized zirconium metal-organic frameworks uio-66, -67, -68 and analogues. J. Mater. Chem. C, 2:7111-7125, 2014.

[9] Yeob Lee, Sangjun Kim, Jeung Ku Kang, and Seth M. Cohen. Photocatalytic co2 reduction by a mixed metal (zr/ti), mixed ligand metal-organic framework under visible light irradiation. Chem. Commun., 51:5735-5738, 2015.

[10] Zhou Sha, Jiulong Sun, Hardy Sze On Chan, Stephan Jaenicke, and Jishan Wu. Bismuth tungstate incorporated zirconium metal-organic framework composite with enhanced visible-light photocatalytic performance. RSC Adv., 4:64977-64984, 2014.

[11] Terence Musho, Jiangtian Li, and Nianqiang Wu. Band gap modulation of functionalized metal-organic frameworks. Phys. Chem. Chem. Phys., 16:23646-23653, 2014.

[12] Christopher H. Hendon, Davide Tiana, Marc Fontecave, Clment Sanchez, Loc Darras, Capucine Sassoye, Laurence Rozes, Caroline Mellot-Draznieks, and Aron Walsh. Engineering the optical response of the titanium-mil-125 metalorganic framework through ligand functionalization. Journal of the American Chemical Society, 135(30):10942$10945,2013$.

[13] Li Hailian, Eddaoudi Mohamed, M. O'Keeffe, and O. M. Yaghi. Design and synthesis of an exceptionally stable and highly porous metal-organic framework. Nature, 402(6759):279, 1999.

[14] Christopher H. Hendon, Davide Tiana, and Aron Walsh. Conductive metal-organic frameworks and networks: fact or fantasy? Phys. Chem. Chem. Phys., 14:13120-13132, 2012.

[15] Terence Musho and Nianqiang Wu. Ab initio calculation of electronic charge mobility in metal-organic frameworks. Phys. Chem. Chem. Phys., 17:26160-26165, 2015. 
[16] Paolo Giannozzi, Stefano Baroni, Nicola Bonini, Matteo Calandra, Roberto Car, Carlo Cavazzoni, Davide Ceresoli, Guido L Chiarotti, Matteo Cococcioni, Ismaila Dabo, Andrea Dal Corso, Stefano de Gironcoli, Stefano Fabris, Guido Fratesi, Ralph Gebauer, Uwe Gerstmann, Christos Gougoussis, Anton Kokalj, Michele Lazzeri, Layla MartinSamos, Nicola Marzari, Francesco Mauri, Riccardo Mazzarello, Stefano Paolini, Alfredo Pasquarello, Lorenzo Paulatto, Carlo Sbraccia, Sandro Scandolo, Gabriele Sclauzero, Ari P Seitsonen, Alexander Smogunov, Paolo Umari, and Renata M Wentzcovitch. Quantum espresso: a modular and open-source software project for quantum simulations of materials. Journal of Physics: Condensed Matter, 21(39):395502, 2009.

[17] Jin-Liang Wang, Cheng Wang, and Wenbin Lin. Metal-organic frameworks for light harvesting and photocatalysis. ACS Catalysis, 2(12):2630-2640, 2012.

[18] Maxim A. Nasalevich, Maarten G. Goesten, Tom J. Savenije, Freek Kapteijn, and Jorge Gascon. Enhancing optical absorption of metal-organic frameworks for improved visible light photocatalysis. Chem. Commun., 49:10575-10577, 2013.

[19] Yang Peng, Vaiva Krungleviciute, Ibrahim Eryazici, Joseph T. Hupp, Omar K. Farha, and Taner Yildirim. Methane storage in metal-organic frameworks: Current records, surprise findings, and challenges. Journal of the American Chemical Society, 135(32):11887-11894, 2013.

[20] Qingyuan Yang and Chongli Zhong. Understanding hydrogen adsorption in metalorganic frameworks with open metal sites: a computational study. The Journal of Physical Chemistry B, 110(2):655-658, 2006.

[21] Mohamed Eddaoudi, David B. Moler, Hailian Li, Banglin Chen, Theresa M. Reineke, Michael O'Keeffe, , and Omar M. Yaghi. Modular chemistry: secondary building units as a basis for the design of highly porous and robust metalorganic carboxylate frameworks. Accounts of Chemical Research, 34(4):319-330, 2001. 
[22] Andrew R. Millward, , and Omar M. Yaghi. Metalorganic frameworks with exceptionally high capacity for storage of carbon dioxide at room temperature. Journal of the American Chemical Society, 127(51):17998-17999, 2005.

[23] Stuart L. James. Metal-organic frameworks. Chem. Soc. Rev., 32:276-288, 2003.

[24] JeongYong Lee, Omar K. Farha, John Roberts, Karl A. Scheidt, SonBinh T. Nguyen, and Joseph T. Hupp. Metal-organic framework materials as catalysts. Chem. Soc. Rev., $38: 1450-1459,2009$.

[25] Ugo Ravon, Marcelo E. Domine, Cyril Gaudillere, Arnold Desmartin-Chomel, and David Farrusseng. Mofs as acid catalysts with shape selectivity properties. New J. Chem., 32:937-940, 2008.

[26] Michael J. Ingleson, Jorge Perez Barrio, John Bacsa, Calum Dickinson, Hyunsoo Park, and Matthew J. Rosseinsky. Generation of a solid bronsted acid site in a chiral framework. Chem. Commun., pages 1287-1289, 2008.

[27] Franesc X. Llabrs i Xamena, Alberto Abad, Avelino Corma, and Hermenegildo Garcia. \{MOFs\} as catalysts: Activity, reusability and shape-selectivity of a pd-containing \{MOF\}. Journal of Catalysis, 250(2):294 - 298, 2007.

[28] Makoto Fujita, Yoon Jung Kwon, Satoru Washizu, and Katsuyuki Ogura. Preparation, clathration ability, and catalysis of a two-dimensional square network material composed of cadmium(ii) and 4,4'-bipyridine. Journal of the American Chemical Society, 116(3):1151-1152, 1994.

[29] So-Hye Cho, Baoqing Ma, SonBinh T. Nguyen, Joseph T. Hupp, and Thomas E. Albrecht-Schmitt. A metal-organic framework material that functions as an enantioselective catalyst for olefin epoxidation. Chem. Commun., pages 2563-2565, 2006. 
[30] Bo Xiao, Hongwei Hou, and Yaoting Fan. Catalytic applications of cuii-containing $\{$ MOFs $\}$ based on n-heterocyclic ligand in the oxidative coupling of 2,6-dimethylphenol. Journal of Organometallic Chemistry, 692(10):2014 - 2020, 2007.

[31] Loredana Valenzano, Bartolomeo Civalleri, Sachin Chavan, Silvia Bordiga, Merete H. Nilsen, S. Jakobsen, Karl Petter Lillerud, and Carlo Lamberti. Disclosing the complex structure of uio-66 metal organic framework: A synergic combination of experiment and theory. Chemistry of Materials, 23(7):1700-1718, 2011.

[32] Stefan Grimme. Semiempirical gga-type density functional constructed with a longrange dispersion correction. Journal of Computational Chemistry, 27(15):1787-1799, 2006.

[33] Vincenzo Barone, Maurizio Casarin, Daniel Forrer, Michele Pavone, Mauro Sambi, and Andrea Vittadini. Role and effective treatment of dispersive forces in materials: Polyethylene and graphite crystals as test cases. Journal of Computational Chemistry, 30(6):934-939, 2009.

[34] Aoning Wang, Yingjie Zhou, Zhoulu Wang, Miao Chen, Luyi Sun, and Xiang Liu. Titanium incorporated with uio-66(zr)-type metal-organic framework (mof) for photocatalytic application. RSC Adv., 6:3671-3679, 2016.

[35] Kevin Hendrickx, Danny E. P. Vanpoucke, Karen Leus, Kurt Lejaeghere, Andy Van Yperen-De Deyne, Veronique Van Speybroeck, Pascal Van Der Voort, and Karen Hemelsoet. Understanding intrinsic light absorption properties of uio-66 frameworks: A combined theoretical and experimental study. Inorganic Chemistry, 54(22):10701-10710, 2015.

[36] Shinpei Hasegawa, Satoshi Horike, Ryotaro Matsuda, Shuhei Furukawa, Katsunori Mochizuki, Yoshinori Kinoshita, and Susumu Kitagawa. Three-dimensional porous coordination polymer functionalized with amide groups based on tridentate ligand: selective 
sorption and catalysis. Journal of the American Chemical Society, 129(9):2607-2614, 2007.

[37] Chuan-De Wu, Aiguo Hu, Lin Zhang, and Wenbin Lin. A homochiral porous metalorganic framework for highly enantioselective heterogeneous asymmetric catalysis. Journal of the American Chemical Society, 127(25):8940-8941, 2005.

[38] Ying Lu, Markus Tonigold, Bjrn Bredenktter, Dirk Volkmer, Julia Hitzbleck, and Gerhard Langstein. A cobalt(ii)-containing metal-organic framework showing catalytic activity in oxidation reactions. Zeitschrift fr anorganische und allgemeine Chemie, 634(1213):2411-2417, 2008.

[39] YoungKyu Hwang, Do-Young Hong, Jong-San Chang, SungHwa Jhung, You-Kyong Seo, Jinheung Kim, Alexandre Vimont, Marco Daturi, Christian Serre, and Grard Frey. Amine grafting on coordinatively unsaturated metal centers of mofs: Consequences for catalysis and metal encapsulation. Angewandte Chemie International Edition, 47(22):4144-4148, 2008.

[40] N.V. Maksimchuk, M.N. Timofeeva, M.S. Melgunov, A.N. Shmakov, Yu.A. Chesalov, D.N. Dybtsev, V.P. Fedin, and O.A. Kholdeeva. Heterogeneous selective oxidation catalysts based on coordination polymer mil-101 and transition metal-substituted polyoxometalates. Journal of Catalysis, 257(2):315 - 323, 2008.

[41] F.X. Llabrs i Xamena, O. Casanova, R. Galiasso Tailleur, H. Garcia, and A. Corma. Metal organic frameworks (mofs) as catalysts: A combination of cu2+ and co2+ \{MOFs\} as an efficient catalyst for tetralin oxidation. Journal of Catalysis, 255(2):220 $-227,2008$.

[42] Dongmei Jiang, Tamas Mallat, Frank Krumeich, and Alfons Baiker. Copper-based metal-organic framework for the facile ring-opening of epoxides. Journal of Catalysis, 257(2):390 - 395, 2008. 
[43] Avijit Pramanik, Srinivas Abbina, and Gopal Das. Molecular, supramolecular structure and catalytic activity of transition metal complexes of phenoxy acetic acid derivatives. Polyhedron, 26(18):5225 - 5234, 2007.

[44] Luc Alaerts, Etienne Sguin, Hilde Poelman, Frdric Thibault-Starzyk, Pierre A. Jacobs, and Dirk E. De Vos. Probing the lewis acidity and catalytic activity of the metalorganic framework [cu3(btc)2] (btc=benzene-1,3,5-tricarboxylate). Chemistry A European Journal, 12(28):7353-7363, 2006.

[45] Salvatore De Rosa, Girolamo Giordano, Teresa Granato, Andrea Katovic, Alessio Siciliano, and Francesco Tripicchio. Chemical pretreatment of olive oil mill wastewater using a metal-organic framework catalyst. Journal of Agricultural and Food Chemistry, 53(21):8306-8309, 2005.

[46] Klaus Schlichte, Tobias Kratzke, and Stefan Kaskel. Improved synthesis, thermal stability and catalytic properties of the metal-organic framework compound cu3(btc)2. Microporous and Mesoporous Materials, 73(12):81 - 88, 2004. Metal-Organic Open Frameworks.

[47] F. Gndara, B. Gomez-Lor, E. Gutirrez-Puebla, M. Iglesias, M. A. Monge, D. M. Proserpio, and N. Snejko. An indium layered mof as recyclable lewis acid catalyst. Chemistry of Materials, 20(1):72-76, 2008.

[48] B. Gomez-Lor, E. Gutirrez-Puebla, M. Iglesias, M. A. Monge, C. Ruiz-Valero, and N. Snejko. In2(oh)3(bdc)1.5 (bdc = 1,4-benzendicarboxylate): an in(iii) supramolecular 3d framework with catalytic activity. Inorganic Chemistry, 41(9):2429-2432, 2002.

[49] Mohamed H. Alkordi, Yunling Liu, Randy W. Larsen, Jarrod F. Eubank, and Mohamed Eddaoudi. Zeolite-like metalorganic frameworks as platforms for applications: On metalloporphyrin-based catalysts. Journal of the American Chemical Society, 130(38):12639-12641, 2008. 
[50] Felipe Gndara, Alberto Garca-Corts, Concepcin Cascales, Berta Gmez-Lor, Enrique Gutirrez-Puebla, Marta Iglesias, Angeles Monge, and Natalia Snejko. Rare earth arenedisulfonate metalorganic frameworks: an approach toward polyhedral diversity and variety of functional compounds. Inorganic Chemistry, 46(9):3475-3484, 2007.

[51] Kenneth S. Suslick, P. Bhyrappa, J.-H. Chou, Margaret E. Kosal, Shirley Nakagaki, Dennis W. Smithenry, and Scott R. Wilson. Microporous porphyrin solids. Accounts of Chemical Research, 38(4):283-291, 2005.

[52] Satoshi Horike, Mircea Dinc, Kentaro Tamaki, and Jeffrey R. Long. Size-selective lewis acid catalysis in a microporous metal-organic framework with exposed mn $2+$ coordination sites. Journal of the American Chemical Society, 130(18):5854-5855, 2008.

[53] Ru-Qiang Zou, Hiroaki Sakurai, and Qiang Xu. Preparation, adsorption properties, and catalytic activity of $3 \mathrm{~d}$ porous metalorganic frameworks composed of cubic building blocks and alkali-metal ions. Angewandte Chemie International Edition, 45(16):2542$2546,2006$.

[54] Jong Woo Han and Craig L. Hill. A coordination network that catalyzes o2-based oxidations. Journal of the American Chemical Society, 129(49):15094-15095, 2007.

[55] Abraham M. Shultz, Omar K. Farha, Joseph T. Hupp, and SonBinh T. Nguyen. A catalytically active, permanently microporous mof with metalloporphyrin struts. Journal of the American Chemical Society, 131(12):4204-4205, 2009.

[56] Jung Soo Seo, Dongmok Whang, Hyoyoung Lee, Sung Im Jun, Jinho Oh, Young Jin Jeon, and Kimoon Kim. A homochiral metal-organic porous material for enantioselective separation and catalysis. Nature, 404:982 - 986, 2000. 


\section{APPENDIX A}

\section{Cataloged Research of MOFs}

Table A.1 MOFs as Catalyst

\begin{tabular}{|c|c|c|c|}
\hline No. & Title of Publication & MOF Formula Name & Application of MOF \\
\hline 1 & $\begin{array}{l}\text { Elucidating Molecular Iridium Water Oxida- } \\
\text { tion Catalysts Using Metal-Organic Frame- } \\
\text { works: A Comprehensive Structural, Cat- } \\
\text { alytic, Spectroscopic, and Kinetic Study }\end{array}$ & MOF 1 and 2 & $\begin{array}{l}\text { water oxidation activity, } \\
\text { catalyst }\end{array}$ \\
\hline 2 & $\begin{array}{l}\text { Porous Metall organic Frameworks Con- } \\
\text { structed from Metal 5,10,15,20-Tetrakis (3,5- } \\
\text { biscarboxylphenyl)porphyrin for Highly Effi- } \\
\text { cient and Selective Catalytic Oxidation of } \\
\text { Alkylbenzenes }\end{array}$ & ZJU-18, ZJU-19, ZJU-20 & $\begin{array}{l}\text { Highly Efficient and Selec- } \\
\text { tive Catalytic Oxidation } \\
\text { of Alkylbenzenes }\end{array}$ \\
\hline 3 & $\begin{array}{l}\text { Lab-in-a-Shell: Encapsulating Metal Clusters } \\
\text { for Size Sieving Catalysis }\end{array}$ & $\mathrm{Pd} /$ Silica nanoparticles & $\begin{array}{l}\text { catalysis in allylic oxida- } \\
\text { tion's of substrates }\end{array}$ \\
\hline 4 & $\begin{array}{l}\text { Engineering Chiral Polyoxometalate Hybrid } \\
\text { Metal-Organic Frameworks for Asymmetric } \\
\text { Dihydroxylation of Olefins }\end{array}$ & Ni-PYI1 and Ni-PYI2 & $\begin{array}{l}\text { amphipathic catalyst to } \\
\text { prompt the asymmetric } \\
\text { dihydroxylation of aryl } \\
\text { olefins }\end{array}$ \\
\hline 5 & $\begin{array}{l}\text { Isoreticular Chiral Metal-Organic Frameworks } \\
\text { for Asymmetric Alkene Epoxidation: Tuning } \\
\text { Catalytic Activity by Controlling Framework } \\
\text { Catenation and Varying Open Channel Sizes }\end{array}$ & $\mathrm{Zn} 4(-4-\mathrm{O})(\mathrm{O} 2 \mathrm{CR}) 6$ & $\begin{array}{l}\text { highly effective catalysts } \\
\text { for asymmetric epoxida- } \\
\text { tion of a variety of unfunc- } \\
\text { tionalized olefins }\end{array}$ \\
\hline 6 & $\begin{array}{l}\text { Template-Directed Synthesis of Nets Based } \\
\text { upon Octahemioctahedral Cages That Encap- } \\
\text { sulate Catalytically Active Metalloporphyrins }\end{array}$ & $\begin{array}{l}\mathrm{M}(\mathrm{II}) \mathrm{Cl} 2(\mathrm{M}=\mathrm{Fe}, \mathrm{Co}, \\
\mathrm{Mn}) \text { with } \mathrm{BTC} \text { and } \\
\mathrm{TMPyP} \text { in } \mathrm{DMF} \text { and } \\
\mathrm{H} 2 \mathrm{O}\end{array}$ & $\begin{array}{l}\text { serve as size-selective het- } \\
\text { erogeneous catalysts for } \\
\text { oxidation of olefins }\end{array}$ \\
\hline
\end{tabular}




\begin{tabular}{|c|c|c|c|}
\hline 7 & $\begin{array}{l}\text { Zeolite-like Metal-Organic Frameworks } \\
\text { as Platforms for Applications: On } \\
\text { Metalloporphyrin-Based Catalysts }\end{array}$ & H2TMPyP4+ & $\begin{array}{l}\text { catalytic activity toward } \\
\text { the oxidationof cyclohex- } \\
\text { ane }\end{array}$ \\
\hline 8 & $\begin{array}{l}\text { NH2- Dianion Entrapped in a Nanoporous } \\
\text { 12CaO7Al2O3 Crystal by Ammonothermal } \\
\text { Treatment: Reaction Pathways, Dynamics, } \\
\text { and Chemical Stability }\end{array}$ & $\begin{array}{l}{[\mathrm{Ca} 24 \mathrm{Al} 28 \mathrm{O} 64] 4+(\mathrm{e}-} \\
) 4 \\
{[\mathrm{Ca} 24 \mathrm{Al} 28 \mathrm{O} 64] 4+(\mathrm{O} 2-} \\
) 2\end{array}$ & $\begin{array}{l}\text { hydrogen storage and } \\
\text { base-catalyzed reactions }\end{array}$ \\
\hline 9 & $\begin{array}{l}\text { Adsorption/catalytic properties of MIL-125 } \\
\text { and NH2-MIL-125 }\end{array}$ & $\begin{array}{l}\text { MIL-125 and NH2-MIL- } \\
125\end{array}$ & catalytic properties \\
\hline 10 & $\begin{array}{l}\text { Applications of metal-organic frameworks in } \\
\text { heterogeneous supramolecular catalysis }\end{array}$ & MOFs & $\begin{array}{l}\text { heterogeneous } \\
\text { supramolecular catal- } \\
\text { ysis }\end{array}$ \\
\hline 11 & $\begin{array}{l}\text { Zeolitic Imidazole Framework- } 67 \text { (ZIF-67) as } \\
\text { a heterogeneous catalyst to activate peroxy- } \\
\text { monosulfate for degradation of Rhodamine B } \\
\text { in water }\end{array}$ & ZIF-67 & $\begin{array}{l}\text { heterogeneous catalyst to } \\
\text { activate peroxymonosul- } \\
\text { fate for degradation of } \\
\text { Rhodamine B in water }\end{array}$ \\
\hline 12 & $\begin{array}{l}\text { Photocatalytic } \mathrm{CO} 2 \text { reduction by } \mathrm{CdS} \text { pro- } \\
\text { moted with a zeolitic imidazolate framework }\end{array}$ & Co-ZIF-9/CdS & $\begin{array}{l}\text { Photocatalytic } \mathrm{CO} 2 \text { re- } \\
\text { duction }\end{array}$ \\
\hline 13 & $\begin{array}{l}\text { Determination of the electronic and structural } \\
\text { configuration of coordination compounds by } \\
\text { synchrotron-radiation techniques }\end{array}$ & MOFs & Homogeneous catalysis \\
\hline 14 & $\begin{array}{l}\text { Photocatalytic } \mathrm{CO} 2 \text { reduction in metal- } \\
\text { organic frameworks: A mini review }\end{array}$ & NH2-MIL-125(Ti) & $\begin{array}{l}\text { Photocatalytic } \mathrm{CO} 2 \text { re- } \\
\text { duction }\end{array}$ \\
\hline 15 & $\begin{array}{l}\text { Metal-organic frameworks in fuel cell tech- } \\
\text { nologies }\end{array}$ & $\begin{array}{l}\text { (Zn4O(bdc- } \\
\text { NH2)3,IRMOF-3 }\end{array}$ & $\begin{array}{l}\text { photocatalysts, electro- } \\
\text { catalysts }\end{array}$ \\
\hline 16 & $\begin{array}{l}\text { Heteroatoms ternary-doped porous carbons } \\
\text { derived from MOFs as metal-free electrocat- } \\
\text { alysts for oxygen reduction reaction }\end{array}$ & NPS-C-MOF-5 & $\begin{array}{l}\text { electrocatalysts for oxy- } \\
\text { gen reduction reaction }\end{array}$ \\
\hline 17 & $\begin{array}{l}\text { Metal organic framework-mediated synthesis } \\
\text { of highly active and stable Fischer-Tropsch } \\
\text { catalysts }\end{array}$ & (-Fe(BTC), C9H3FeO6 & $\begin{array}{l}\text { highly active and stable } \\
\text { Fischer-Tropsch catalysts }\end{array}$ \\
\hline
\end{tabular}




\begin{tabular}{|c|c|c|c|}
\hline 18 & $\begin{array}{l}\text { Iron-based cathode catalyst with enhanced } \\
\text { power density in polymer electrolyte mem- } \\
\text { brane fuel cells }\end{array}$ & zeolitic-imidazolate & $\begin{array}{l}\text { cathode catalyst with en- } \\
\text { hanced power density }\end{array}$ \\
\hline 19 & $\begin{array}{l}\text { Catalysis by metal-organic frameworks in wa- } \\
\text { ter }\end{array}$ & $\begin{array}{l}\text { MIL-101(Cr), MIL-53(Al) } \\
\text { and ZIF-8 }\end{array}$ & Catalysis \\
\hline 20 & $\begin{array}{l}\text { Towards acid MOFs - catalytic performance } \\
\text { of sulfonic acid functionalized architectures }\end{array}$ & $\begin{array}{l}\text { MIL-101(Cr), HSO3-MIL- } \\
101(\mathrm{Cr})\end{array}$ & $\begin{array}{l}\text { catalytic performance of } \\
\text { sulfonic acid functional- } \\
\text { ized architectures }\end{array}$ \\
\hline 21 & $\begin{array}{l}\text { Enhancing the hydrostability and catalytic } \\
\text { performance of metal-organic frameworks by } \\
\text { hybridizing with attapulgite, a natural clay }\end{array}$ & $\mathrm{MOF}-5[\mathrm{Zn} 4 \mathrm{O}(\mathrm{BDC}) 3$ & $\begin{array}{l}\text { Enhancing the hydrosta- } \\
\text { bility and catalytic perfor- } \\
\text { mance }\end{array}$ \\
\hline 22 & $\begin{array}{l}\text { Hydrogen adsorption in } \mathrm{Pt} \text { catalyst/MOF-5 } \\
\text { materials }\end{array}$ & MOF-5 & $\begin{array}{l}\text { Hydrogen adsorption in } \\
\text { Pt catalyst/MOF-5 mate- } \\
\text { rials }\end{array}$ \\
\hline 23 & $\begin{array}{l}\text { Multifunctional Metal-Organic Frameworks } \\
\text { for Photocatalysis }\end{array}$ & $\mathrm{MOF}$ & Photocatalysis \\
\hline 24 & $\begin{array}{l}\text { Lipase-Supported Metal-Organic Framework } \\
\text { Bioreactor Catalyzes Warfarin Synthesis }\end{array}$ & UiO-66, MlL-53, SBA-15 & $\begin{array}{l}\text { Bioreactor Catalyzes War- } \\
\text { farin Synthesis }\end{array}$ \\
\hline 25 & $\begin{array}{l}\text { Porous crystals as active catalysts for the syn- } \\
\text { thesis of cyclic carbonates }\end{array}$ & $\mathrm{MOF}$ & active catalysts \\
\hline 26 & $\begin{array}{l}\text { Engineering Homochiral Metal-Organic } \\
\text { Frameworks for Heterogeneous Asymmetric } \\
\text { Catalysis and Enantioselective Separation }\end{array}$ & $\mathrm{MOF}$ & $\begin{array}{l}\text { Heterogeneous Asymmet- } \\
\text { ric Catalysis and Enan- } \\
\text { tioselective Separation } \\
\end{array}$ \\
\hline 27 & $\begin{array}{l}\text { Pt@MOF-177: Synthesis, Room-Temperature } \\
\text { Hydrogen Storage and Oxidation Catalysis }\end{array}$ & Pt@MOF-177 & $\begin{array}{l}\text { Hydrogen Storage and } \\
\text { Oxidation Catalysis }\end{array}$ \\
\hline 28 & $\begin{array}{l}\text { Catalytic Transesterifications by a Zn- } \\
\text { BisSalen MOF Containing Open Pyridyl } \\
\text { Groups Inside 1D Channels }\end{array}$ & Zn-BisSalen MOF & $\begin{array}{l}\text { active catalyst for transes- } \\
\text { terifications }\end{array}$ \\
\hline 29 & $\begin{array}{l}\text { Structure and Catalytic Activity of New } \\
\text { Metal-Organic Frameworks Based on Copper } \\
\text { Cyanide and Quinoline Bases }\end{array}$ & $\begin{array}{l}\text { Copper Cyanide and } \\
\text { Quinoline Bases MOF }\end{array}$ & $\begin{array}{l}\text { Structure and Catalytic } \\
\text { Activity }\end{array}$ \\
\hline
\end{tabular}




\begin{tabular}{|c|c|c|c|}
\hline 30 & $\begin{array}{l}\text { Poly(ethylene glycol) Stabilized Mesoporous } \\
\text { Metal-Organic Framework Nanocrystals: Effi- } \\
\text { cient and Durable Catalysts for the Oxidation } \\
\text { of Benzyl Alcohol }\end{array}$ & $\mathrm{Cu} 3(\mathrm{BTC}) 2$ & $\begin{array}{l}\text { Efficient and Durable Cat- } \\
\text { alysts for the Oxidation of } \\
\text { Benzyl Alcohol }\end{array}$ \\
\hline 31 & $\begin{array}{l}\text { Structure, photoluminescent properties and } \\
\text { photocatalytic activities of a new } \mathrm{Cd}(\mathrm{II}) \\
\text { metal-organic framework. }\end{array}$ & {$[\mathrm{Cd}(\mathrm{TDC})(\mathrm{bix})(\mathrm{H} 2 \mathrm{O})] \mathrm{n}$} & $\begin{array}{l}\text { photoluminescent proper- } \\
\text { ties and photocatalytic }\end{array}$ \\
\hline 32 & $\begin{array}{l}\text { Pd-grafted porous metal-organic framework } \\
\text { material as an efficient and reusable hetero- } \\
\text { geneous catalyst for C-C coupling reactions in } \\
\text { water }\end{array}$ & $\operatorname{Pd}(0) / \mathrm{MCoS}-1$ & catalytic \\
\hline 33 & $\begin{array}{l}\text { Efficient Suzuki-Miyaura coupling reaction in } \\
\text { water: Stabilized Pdo-Montmorillonite clay } \\
\text { composites catalyzed reaction }\end{array}$ & Pdo-Montmorillonite & catalyzed reaction \\
\hline 34 & $\begin{array}{l}\text { Magnetically recyclable Fe@Pd/C as a highly } \\
\text { active catalyst for Suzuki coupling reaction in } \\
\text { aqueous solution }\end{array}$ & $\mathrm{Fe} @ \mathrm{Pd} / \mathrm{C}$ & $\begin{array}{l}\text { active catalyst for Suzuki } \\
\text { coupling }\end{array}$ \\
\hline 35 & $\begin{array}{l}\text { Metal-organic framework templated synthesis } \\
\text { of } \mathrm{Fe} 2 \mathrm{O} 3 / \mathrm{TiO} 2 \text { nanocomposite for hydrogen } \\
\text { production. }\end{array}$ & $\mathrm{Fe}(2) \mathrm{O}(3) / \mathrm{TiO}(2)$ & $\begin{array}{l}\text { interesting photophysical } \\
\text { properties }\end{array}$ \\
\hline 36 & $\begin{array}{l}\text { Metal-organic framework based upon the syn- } \\
\text { ergy of a Br-nsted acid framework and Lewis } \\
\text { acid centers as a highly efficient heterogeneous } \\
\text { catalyst for fixed-bed reactions. }\end{array}$ & $\begin{array}{l}\text { Metal-organic framework } \\
\text { based upon the synergy of } \\
\text { a Br-nsted acid framework } \\
\text { and Lewis acid centers as } \\
\text { a highly efficient hetero- } \\
\text { geneous catalyst for fixed- } \\
\text { bed reactions. }\end{array}$ & high catalytic activity \\
\hline 37 & $\begin{array}{l}\text { Chelating agent-free, vapor-assisted crystal- } \\
\text { lization method to synthesize hierarchical mi- } \\
\text { croporous/mesoporous MIL-125 (Ti). }\end{array}$ & MIL-125 (Ti) & heterogeneous catalysts \\
\hline
\end{tabular}




\begin{tabular}{|c|c|c|c|}
\hline 38 & $\begin{array}{l}\text { Nanoscaled copper metal-organic framework } \\
\text { (MOF) based on carboxylate ligands as an effi- } \\
\text { cient heterogeneous catalyst for aerobic epoxi- } \\
\text { dation of olefins and oxidation of benzylic and } \\
\text { allylic alcohols. }\end{array}$ & & heterogeneous catalyst \\
\hline 39 & $\begin{array}{l}\text { Highly functionalized biaryls via Suzuki- } \\
\text { Miyaura cross-coupling catalyzed by } \\
\text { Pd@MOFunder batch and continuous flow } \\
\text { regimes. }\end{array}$ & Pd@MIL-101(Cr)-NH2 & cross-coupling catalyzed \\
\hline 40 & $\begin{array}{l}\text { A } \mathrm{Ni}(\mathrm{II})-\mathrm{MOF} \text { : reversible guest adsorption } \\
\text { and heterogeneous catalytic properties for } \\
\text { silylcyanation of aromatic aldehydes. }\end{array}$ & $\mathrm{Ni}(\mathrm{II})-\mathrm{MOF}$ & $\begin{array}{l}\text { reversible guest adsorp- } \\
\text { tion and heterogeneous } \\
\text { catalytic properties }\end{array}$ \\
\hline 41 & $\begin{array}{l}\text { Reversible conversion of valence-tautomeric } \\
\text { copper metal-organic frameworks depen- } \\
\text { dent single-crystal-to-single-crystal oxida- } \\
\text { tion/reduction: a redox-switchablecatalyst } \\
\text { for C-H bonds activation reaction. }\end{array}$ & zeolite-like $\mathrm{Cu}$ & $\begin{array}{l}\text { redox-switchablecatalyst } \\
\text { for } \mathrm{C}-\mathrm{H} \text { bonds activation } \\
\text { reaction }\end{array}$ \\
\hline 42 & $\begin{array}{l}\text { A bifunctional, site-isolated metal-organic } \\
\text { framework-based tandem catalyst. }\end{array}$ & $\begin{array}{l}\text { Zn(II)-based IRMOF-9- } \\
\text { Irdcppy-NH2 }\end{array}$ & andem catalyst \\
\hline 43 & $\begin{array}{l}\text { Coordinated assembly of a new 3D meso- } \\
\text { porous Fe-O-@Cu-O-graphene oxideframe- } \\
\text { work as a highly efficient and reusable catalyst } \\
\text { for the synthesis of quinoxalines. }\end{array}$ & $\mathrm{Fe}-\mathrm{O}-@ \mathrm{Cu}-\mathrm{O}$ & $\begin{array}{l}\text { highly efficient and } \\
\text { reusable catalyst for the } \\
\text { synthesis of quinoxalines }\end{array}$ \\
\hline 44 & $\begin{array}{l}\text { The synthesis, structure, topology and cat- } \\
\text { alytic application of a novel cubane-based cop- } \\
\text { per(ii) metal-organic framework derived from } \\
\text { a flexible amido tripodal acid. }\end{array}$ & $\begin{array}{l}{[\mathrm{Cu} 4(\mathrm{HL}) 2} \\
(\mathrm{H} 2 \mathrm{O}) 4(\mathrm{MeO}) 4] \mathrm{n}\end{array}$ & $\begin{array}{lr}\text { synthesis, } & \text { structure, } \\
\text { topology and catalytic } \\
\text { application }\end{array}$ \\
\hline 45 & $\begin{array}{l}\text { A polyoxometalate-encapsulating cationic } \\
\text { metal-organic framework as a heterogeneous- } \\
\text { catalyst for desulfurization. }\end{array}$ & $\begin{array}{l}\mathrm{Co}(\mathrm{BBPTZ}) 3] \\
{[\mathrm{HPMo12O} 40]-24-\mathrm{H} 2 \mathrm{O}}\end{array}$ & $\begin{array}{l}\text { heterogeneouscatalyst for } \\
\text { desulfurization }\end{array}$ \\
\hline
\end{tabular}


Table A.2 Common Photocatalytic MOFs

\begin{tabular}{|c|c|c|c|}
\hline No. & Title of Publication & MOF Formula Name & Application of MOF \\
\hline 1 & $\begin{array}{l}\text { Doping Metal-Organic Frameworks for Water } \\
\text { Oxidation, Carbon Dioxide Reduction, and } \\
\text { Organic Photocatalysis }\end{array}$ & $\begin{array}{l}\mathrm{Zr} 6 \mathrm{O} 4(\mathrm{OH}) 4(\mathrm{bpdc}) 6 \\
\mathrm{UiO}-67\end{array}$ & $\begin{array}{l}\text { developing highly active } \\
\text { heterogeneous catalysts } \\
\text { for solar energy utilization }\end{array}$ \\
\hline 2 & $\begin{array}{l}\text { Light Harvesting in Microscale Metal-Organic } \\
\text { Frameworks by Energy Migration and Inter- } \\
\text { facial Electron Transfer Quenching }\end{array}$ & photoactive $\mathrm{Ru}(\mathrm{II})$-bpy & light absorption \\
\hline 3 & $\begin{array}{l}\text { Photoactive Chiral Metal-Organic Frame- } \\
\text { works for Light-Driven Asymmetric - } \\
\text { Alkylation of Aldehydes }\end{array}$ & Zn-PYI1 and Zn-PYI2 & light absorption \\
\hline 4 & $\begin{array}{l}\text { Anthropogenic Chemical Carbon Cycle for a } \\
\text { Sustainable Future }\end{array}$ & MOF 177 Zinc & $\begin{array}{l}\text { sun-s energy with chloro- } \\
\text { phyll in plants as a cat- } \\
\text { alyst to recycle carbon } \\
\text { dioxide and water into } \\
\text { new plant life }\end{array}$ \\
\hline 5 & $\begin{array}{l}\text { Iron(III)-Based Metal-Organic Frameworks } \\
\text { As Visible Light Photocatalysts }\end{array}$ & Fe3-3-oxo clusters & $\begin{array}{l}\text { visible light photocata- } \\
\text { lysts }\end{array}$ \\
\hline 6 & $\begin{array}{l}\text { Versatile, High Quality and Scalable Continu- } \\
\text { ous Flow Production of Metal-Organic Frame- } \\
\text { works }\end{array}$ & $\begin{array}{l}\text { UKUST-1, } \\
\text { NOTT-400 }\end{array}$ & light absorption \\
\hline 7 & $\begin{array}{l}\text { An experimental and simulation study of bi- } \\
\text { nary adsorption in metal-organic frameworks }\end{array}$ & $\mathrm{CO} 2 / \mathrm{N} 2$ and $\mathrm{CO} 2 / \mathrm{CH} 4$ & binary adsorption \\
\hline 8 & $\begin{array}{l}\text { X-ray absorption spectroscopies: useful } \\
\text { tools to understand metallorganic frameworks } \\
\text { structure and reactivity }\end{array}$ & $\mathrm{MOF}$ & $\begin{array}{l}\text { X-ray absorption spectro- } \\
\text { scopies }\end{array}$ \\
\hline 9 & $\begin{array}{l}\text { Tunable Two-color Luminescence and Host- } \\
\text { guest Energy Transfer of Fluorescent Chro- } \\
\text { mophores Encapsulated in Metal-Organic } \\
\text { Frameworks }\end{array}$ & $\begin{array}{l}\text { stilbene-MOF, } \\
\text { DCM@IRMOF-8 }\end{array}$ & $\begin{array}{l}\text { Two-color Luminescence } \\
\text { and Host-guest Energy } \\
\text { Transfer }\end{array}$ \\
\hline
\end{tabular}




\begin{tabular}{|c|c|c|c|}
\hline 10 & $\begin{array}{l}\text { A synthetic route to ultralight hierarchically } \\
\text { micro/mesoporous } \mathrm{Al}(\mathrm{III}) \text {-carboxylate metal- } \\
\text { organic aerogels }\end{array}$ & $\mathrm{Al}(111)$-carboxylate & ultralight hierarchically \\
\hline 11 & $\begin{array}{l}\text { Fluorocarbon adsorption in hierarchical } \\
\text { porous frameworks }\end{array}$ & $\begin{array}{l}\text { MDOBDC , MIL-100(Fe), } \\
\text { MlL-101 }\end{array}$ & Fluorocarbon adsorption \\
\hline 12 & $\begin{array}{l}\text { Enhanced photovoltaic performance of } \mathrm{Cu}- \\
\text { based metal-organic frameworks sensitized so- } \\
\text { lar cell by addition of carbon nanotubes }\end{array}$ & $\begin{array}{l}\mathrm{CU} \operatorname{MOF}(\mathrm{l}) \\
\mathrm{TiO} 2+\mathrm{MWCNT} \\
\mathrm{TiO} 2(\mathrm{HBL})\end{array}$ & $\begin{array}{l}\text { Enhanced photovoltaic } \\
\text { performance of CU MOF }\end{array}$ \\
\hline 13 & Metal-organic framework composites & $\begin{array}{l}\text { M/MIL- } \\
101(\mathrm{M}=\mathrm{Pt}, \mathrm{Pd}, \mathrm{PtPd})\end{array}$ & light adsorption \\
\hline 14 & $\begin{array}{l}\text { Construction of a supported Ru complex on } \\
\text { bifunctional MOF- } 253 \text { for photocatalytic CO } 2 \\
\text { reduction under visible light }\end{array}$ & $\begin{array}{l}\mathrm{MOF}-253, \quad \mathrm{MOF}-253- \\
\mathrm{Ru}(\mathrm{CO}) 2 \mathrm{Cl} 2\end{array}$ & $\begin{array}{l}\text { photocatalytic } \mathrm{CO} 2 \text { re- } \\
\text { duction under visible light }\end{array}$ \\
\hline 15 & $\begin{array}{l}\mathrm{Cu}(\mathrm{II}) \text {-and } \mathrm{Co}(\mathrm{II}) \text {-containing metal-organic } \\
\text { frameworks (MOFs) ascatalysts for cyclohex- } \\
\text { ene oxidation with oxygen under solvent-free } \\
\text { conditions }\end{array}$ & $\mathrm{Cu}-\mathrm{MOF}$ and $\mathrm{Co}-\mathrm{MOF}$ & $\begin{array}{l}\text { cyclohexene oxidation } \\
\text { with oxygen under } \\
\text { solvent-free conditions }\end{array}$ \\
\hline 16 & $\begin{array}{l}\text { A novel acylamide MOF showing self- } \\
\text { catenated hxg-d-4-Fddd nets with 3-fold in- } \\
\text { terpenetration and highly selective adsorption } \\
\text { of } \mathrm{CO} 2 \text { over } \mathrm{N} 2, \mathrm{CH} 4 \text {, and } \mathrm{CO}\end{array}$ & $\mathrm{Zn}(\mathrm{L})($ tdca $) 1.5 \mathrm{DMF}$ & $\begin{array}{l}\text { nterpenetration and } \\
\text { highly selective adsorp- } \\
\text { tion of } \mathrm{CO} 2 \text { over N2, } \\
\mathrm{CH} 4 \text {, and } \mathrm{CO}\end{array}$ \\
\hline 17 & $\begin{array}{l}\text { Adsorption of volatile organic compounds by } \\
\text { metal-organic frameworks MOF-177 }\end{array}$ & MOF-177 & $\begin{array}{l}\text { Adsorption of volatile or- } \\
\text { ganic compounds }\end{array}$ \\
\hline 18 & $\begin{array}{l}\text { Pressure swing adsorption process for the sep- } \\
\text { aration of nitrogen and propylene with a MOF } \\
\text { adsorbent MIL- } 100(\mathrm{Fe})\end{array}$ & MIL-100(Fe) & $\begin{array}{l}\text { adsorption process for the } \\
\text { separation of nitrogen and } \\
\text { propylene }\end{array}$ \\
\hline 19 & $\begin{array}{l}\text { Magnetic Fe3O4@C/Cu and } \mathrm{Fe} 3 \mathrm{O} 4 @ \mathrm{CuO} \\
\text { core-shell composites constructed from MOF- } \\
\text { based materials and their photocatalytic prop- } \\
\text { erties under visible light }\end{array}$ & $\begin{array}{l}\mathrm{Fe} 3 \mathrm{O} 4 @ \mathrm{C} / \mathrm{Cu} \\
\mathrm{Fe} 3 \mathrm{O} 4 @ \mathrm{CuO}\end{array}$ & $\begin{array}{l}\text { photocatalytic properties } \\
\text { under visible light }\end{array}$ \\
\hline
\end{tabular}




\begin{tabular}{|c|c|c|c|}
\hline 20 & $\begin{array}{l}\text { A } 3 \mathrm{D} \text { porous zinc MOF constructed from a } \\
\text { flexible tripodal ligand: Synthesis, structure, } \\
\text { and photoluminescence property }\end{array}$ & zinc $\mathrm{MOF}$ & $\begin{array}{l}\text { Synthesis, structure, and } \\
\text { photoluminescence prop- } \\
\text { erty }\end{array}$ \\
\hline 21 & $\begin{array}{l}\text { Metal-Organic Frameworks with Exception- } \\
\text { ally High Methane Uptake: Where and How } \\
\text { is Methane Stored- }\end{array}$ & $\begin{array}{l}\text { HKUST-1, PCN-11, and } \\
\text { PCN-14 }\end{array}$ & Mathane Adsorption \\
\hline 22 & $\begin{array}{l}\text { Metal organic framework membranes for car- } \\
\text { bon dioxide separation }\end{array}$ & Various MOF & $\mathrm{CO} 2$ adsorption \\
\hline 23 & $\begin{array}{l}\text { MOF-derived } \mathrm{ZnO} \text { and } \mathrm{ZnO} @ \mathrm{C} \text { composites } \\
\text { with high photocatalytic activity and adsorp- } \\
\text { tion capacity }\end{array}$ & $\mathrm{ZnO}$ and $\mathrm{ZnO} @ \mathrm{C}, \mathrm{MOF}-5$ & photocatalytic \\
\hline 24 & $\begin{array}{l}\text { New photocatalysts based on MIL-53 metal- } \\
\text { organic frameworks for the decolorization of } \\
\text { methylene blue dye }\end{array}$ & MIL-53 & photocatalytic \\
\hline 25 & $\begin{array}{l}\text { MIL-53(Al) mesostructured metal-organic } \\
\text { frameworks }\end{array}$ & & Nitrogen adsorption \\
\hline 26 & $\begin{array}{l}\text { Thermodynamic analysis of the breathing of } \\
\text { amino-functionalized MIL-53(Al) upon } \mathrm{CO} 2 \\
\text { adsorption }\end{array}$ & MIL-53(Al) & $\begin{array}{l}\text { hermodynamic analysis } \\
\text { upon } \mathrm{CO} 2 \text { adsorption }\end{array}$ \\
\hline 27 & $\begin{array}{l}\text { Structures and photocatalytic activities of } \\
\text { metal-organic frameworks derived from rigid } \\
\text { aromatic dicarboxylate acids and flexible } \\
\text { imidazole-based linkers }\end{array}$ & $\mathrm{Cd}(3-\mathrm{NO} 2-\mathrm{bdc})(\mathrm{bbi})$ & $\begin{array}{l}\text { Structures and photocat- } \\
\text { alytic activities }\end{array}$ \\
\hline 28 & $\begin{array}{l}\text { The ionothermal synthesis of a } 3 \mathrm{D} \text { indium } \\
\text { metal-organic framework: Crystal structure, } \\
\text { photoluminescence property and photocat- } \\
\text { alytic activity }\end{array}$ & $\begin{array}{l}\{[\mathrm{EMIM}] 2[\operatorname{InK}(1,2,4,5- \\
\mathrm{BTC}) 1.5(\mathrm{H} 2 \mathrm{O}) 2]\} \mathrm{n}\end{array}$ & $\begin{array}{l}\text { photoluminescence prop- } \\
\text { erty and photocatalytic } \\
\text { activity }\end{array}$ \\
\hline 29 & $\begin{array}{l}\text { Synthesis, structure and photocatalytic prop- } \\
\text { erty of a novel 3D }(3,8) \text {-connected metal- } \\
\text { organic framework based on a flexible triphos- } \\
\text { phonate and a pentanuclear } \mathrm{Cu}(\mathrm{II}) \text { unit }\end{array}$ & $\begin{array}{l}{[\mathrm{Cu} 5(\mathrm{H} 2 \mathrm{~L}) 2(\mathrm{btb}) 2} \\
(\mathrm{OH}) 2] 3 \mathrm{H} 2 \mathrm{O}\end{array}$ & $\begin{array}{l}\text { structure and photocat- } \\
\text { alytic property }\end{array}$ \\
\hline
\end{tabular}




\begin{tabular}{|c|c|c|c|}
\hline 30 & $\begin{array}{l}\text { Structure, photoluminescent properties and } \\
\text { photocatalytic activities of a new } \mathrm{Cd}(\mathrm{II}) \\
\text { metal-organic framework }\end{array}$ & $\mathrm{Cd}(\mathrm{II})$ & $\begin{array}{l}\text { photoluminescent proper- } \\
\text { ties and photocatalytic ac- } \\
\text { tivities }\end{array}$ \\
\hline 31 & $\begin{array}{l}\text { An Amine-Functionalized Titanium Metal- } \\
\text { Organic Framework Photocatalyst with } \\
\text { Visible-Light-Induced Activity for } \mathrm{CO} 2 \\
\text { Reduction- }\end{array}$ & MIL-125(Ti) & $\begin{array}{l}\text { Photocatalyst with } \\
\text { Visible-Light-Induced Ac- } \\
\text { tivity for CO2 Reduction }\end{array}$ \\
\hline 32 & $\begin{array}{l}\text { Fixed distance photoinduced electron transfer } \\
\text { between Fe and Zn porphyrins encapsulated } \\
\text { within the Zn HKUST-1 metal organic frame- } \\
\text { work. }\end{array}$ & Zn HKUST-1 & $\begin{array}{l}\text { Fixed distance photoin- } \\
\text { duced electron transfer }\end{array}$ \\
\hline 33 & $\begin{array}{l}\text { Construction of a supported } \mathrm{Ru} \text { complex on } \\
\text { bifunctional MOF- } 253 \text { for photocatalyticCO2 } \\
\text { reduction under visible light. }\end{array}$ & $\mathrm{MOF}-253-\mathrm{Ru}(\mathrm{CO}) 2 \mathrm{Cl} 2$ & $\begin{array}{l}\text { photocatalyticCO2 reduc- } \\
\text { tion under visible light }\end{array}$ \\
\hline 34 & $\begin{array}{l}\text { Photocatalytic metal-organic framework from } \\
\text { CdS quantum dot incubated luminescent } \\
\text { metallic hydrogen. }\end{array}$ & CdS@ZAVCl) & Photocatalytic MOF \\
\hline 35 & $\begin{array}{l}\text { Incorporation of iron hydrogenase active sites } \\
\text { into a highly stable metal-organic framework } \\
\text { for photocatalytic hydrogen generation. }\end{array}$ & {$[\mathrm{FeFe}] @ \mathrm{ZrPF}$} & $\begin{array}{l}\text { photocatalytic hydrogen } \\
\text { generation }\end{array}$ \\
\hline 36 & $\begin{array}{l}\text { Noble metals can have different effects on } \\
\text { photocatalysis over metal-organic frameworks } \\
\text { (MOFs): a case study on } \mathrm{M} / \mathrm{NH}-\mathrm{MIL}-125(\mathrm{Ti}) \\
(\mathrm{M}=\mathrm{Pt} \text { and } \mathrm{Au})\end{array}$ & $\begin{array}{l}\mathrm{M} / \mathrm{NH} 2-\mathrm{MIL}-125(\mathrm{Ti}) \\
(\mathrm{M}=\mathrm{Pt} \text { and } \mathrm{Au})\end{array}$ & photocatalysis \\
\hline 37 & $\begin{array}{l}\text { Metal-organic frameworks MIL-88A hexago- } \\
\text { nal microrods as a new photocatalyst for ef- } \\
\text { ficient decolorization of methylene blue dye. }\end{array}$ & MIL-88A & $\begin{array}{l}\text { new photocatalyst for ef- } \\
\text { ficient decolorization of } \\
\text { methylene blue dye }\end{array}$ \\
\hline 38 & $\begin{array}{l}\text { Chemical adsorption enhanced } \mathrm{CO} 2 \text { capture } \\
\text { and photoreduction over a copper porphyrin } \\
\text { based metal organic framework. }\end{array}$ & $\mathrm{C} 20 \mathrm{H} 14 \mathrm{CuN} 4$ & $\begin{array}{l}\text { Chemical Adsorption En- } \\
\text { hanced CO2 Capture and } \\
\text { Photoreduction }\end{array}$ \\
\hline
\end{tabular}




\begin{tabular}{|c|c|c|c|}
\hline 39 & $\begin{array}{l}\text { A Zn4O-containing doubly interpenetrated } \\
\text { porous metal-organic framework for photocat- } \\
\text { alytic decomposition of methyl orange. }\end{array}$ & $\mathrm{Zn} 4 \mathrm{O}$ & $\begin{array}{l}\text { photocatalytic decomposi- } \\
\text { tion of methyl orange }\end{array}$ \\
\hline 40 & $\begin{array}{l}\text { A } \operatorname{Sn}(\mathrm{IV}) \text {-porphyrin-based metal-organic } \\
\text { framework for the selective photo-oxygenation } \\
\text { of phenol and sulfides. }\end{array}$ & Sn(IV)-porphyrin & $\begin{array}{l}\text { selective } \\
\text { oxygenation of phenol } \\
\text { and sulfides. }\end{array}$ \\
\hline 41 & $\begin{array}{l}\text { Photocatalytic } \mathrm{CO} 2 \text { reduction by a mixed } \\
\text { metal }(\mathrm{Zr} / \mathrm{Ti}) \text {, mixed ligand metal-organic } \\
\text { framework under visible light irradiation }\end{array}$ & $\begin{array}{l}\text { (PSE) of } \mathrm{Ti}(\mathrm{IV}) \text { into a } \\
\mathrm{Zr}(\mathrm{IV})\end{array}$ & $\begin{array}{l}\text { Photocatalytic } \mathrm{CO} 2 \text { re- } \\
\text { duction }\end{array}$ \\
\hline 42 & $\begin{array}{l}\text { A clean and general strategy to decorate a ti- } \\
\text { tanium metal-organic framework with noble- } \\
\text { metal nanoparticles for versatile photocat- } \\
\text { alytic applications. }\end{array}$ & MIL-125(Ti) & $\begin{array}{l}\text { versatile photocatalytic } \\
\text { applications }\end{array}$ \\
\hline 43 & $\begin{array}{l}\text { A bismuth-based metal-organic framework as } \\
\text { an efficient visible-light-driven photocatalyst. }\end{array}$ & Bi-mna & $\begin{array}{l}\text { visible-light-driven photo- } \\
\text { catalyst }\end{array}$ \\
\hline 44 & $\begin{array}{l}\text { Metal-organic frameworks based on } 1,3,5- \\
\text { triazine-2,4,6-triyltrithio-triacetate: struc- } \\
\text { tures, typologies, photo luminescence and } \\
\text { photocatalytic properties. }\end{array}$ & $\begin{array}{l}\text { 1,3,5-triazine- } 2,4,6- \\
\text { triyltrithio-triacetate }\end{array}$ & $\begin{array}{l}\text { photo luminescence and } \\
\text { photocatalytic properties }\end{array}$ \\
\hline 45 & $\begin{array}{l}\text { An amine-functionalized titanium metal- } \\
\text { organic framework photocatalyst with visible- } \\
\text { light-induced activity for CO2 reduction. }\end{array}$ & NH(2)-MIL-125(Ti) & $\begin{array}{l}\text { photocatalyst with } \\
\text { visible-light-induced ac- } \\
\text { tivity for } \mathrm{CO} 2 \text { reduction }\end{array}$ \\
\hline
\end{tabular}


Table A.3 UiO-66 MOF

\begin{tabular}{|c|c|c|c|}
\hline No. & Title of Publication & MOF Formula Name & Application of MOF \\
\hline 1 & $\begin{array}{l}\text { Synthesis and Stability of Tagged UiO- } 66 \text { Zr- } \\
\text { MOFs }\end{array}$ & $\mathrm{UiO}-66 \mathrm{Zr}$ & catalysis \\
\hline 2 & $\begin{array}{l}\text { Metal-organic framework based highly selec- } \\
\text { tive fluorescenceturn-onprobe for hydrogen } \\
\text { sulphide }\end{array}$ & $\mathrm{UiO}-66 \mathrm{Zr}$ & selective fluorescence \\
\hline 3 & $\begin{array}{l}\text { Structure and Dynamics of the Functionalized } \\
\text { MOF Type UiO-66(Zr): NMR and Dielectric } \\
\text { Relaxation Spectroscopies Coupled with DFT } \\
\text { Calculations }\end{array}$ & $\mathrm{UiO}-66 \mathrm{Zr}$ & gas purification purpose \\
\hline 4 & $\begin{array}{l}\text { Concentration-Dependent Binding of CO2and } \\
\text { CD4in UiO-66(Zr) }\end{array}$ & $\mathrm{UiO}-66 \mathrm{Zr}$ & $\begin{array}{l}\text { Capture of } \mathrm{CO} 2 \text { and sepa- } \\
\text { ration from methane }\end{array}$ \\
\hline 5 & $\begin{array}{l}\text { Improving photocatalytic hydrogen produc- } \\
\text { tion of metal-organic framework UiO- } 66 \text { oc- } \\
\text { tahedrons by dye-sensitization }\end{array}$ & $\mathrm{UiO}-66 \mathrm{Zr}$ & $\begin{array}{l}\text { Improving Photocatalytic } \\
\text { Hydrogen Production }\end{array}$ \\
\hline 6 & $\begin{array}{l}\text { Selective adsorption of cationic dyes by UiO- } \\
66-\mathrm{NH} 2\end{array}$ & Zr-UiO66-BDC-NH2 & $\begin{array}{l}\text { Selective adsorption of } \\
\text { cationic dyes }\end{array}$ \\
\hline 7 & $\begin{array}{l}\text { Adsorption and Diffusion of Light Hydrocar- } \\
\text { bons in UiO-66(Zr): A Combination of Exper- } \\
\text { imental and Modeling Tools }\end{array}$ & $\mathrm{UiO}-66 \mathrm{Zr}$ & $\begin{array}{l}\text { Adsorption and Diffusion } \\
\text { of Light Hydrocarbons }\end{array}$ \\
\hline 8 & $\begin{array}{l}\text { Tuning the Adsorption Properties of UiO- } 66 \\
\text { via Ligand Functionalization }\end{array}$ & $\mathrm{UiO}-66 \mathrm{Zr}$ & $\begin{array}{l}\text { Tuning the Adsorption } \\
\text { Properties }\end{array}$ \\
\hline 9 & $\begin{array}{l}\text { Reverse Shape Selectivity in the Liquid-Phase } \\
\text { Adsorption of Xylene Isomers in Zirconium } \\
\text { Terephthalate MOF UiO-66 }\end{array}$ & $\mathrm{UiO}-66 \mathrm{Zr}$ & $\begin{array}{l}\text { Adsorption of Xylene Iso- } \\
\text { mers }\end{array}$ \\
\hline 10 & $\begin{array}{l}\text { Catalytic behavior of metal-organic frame- } \\
\text { works in the Knoevenagel condensation reac- } \\
\text { tion }\end{array}$ & Zr-UiO66-BDC-NH2 & $\begin{array}{l}\text { Studie for Catalytic prop- } \\
\text { erties and aggects of basic- } \\
\text { ity for UiO-66-NH2 }\end{array}$ \\
\hline
\end{tabular}




\begin{tabular}{|c|c|c|c|}
\hline 11 & $\begin{array}{l}\text { Hexane isomers sorption on a functionalized } \\
\text { metal-organic framework }\end{array}$ & $\mathrm{UiO}-66 \mathrm{Zr}$ & $\begin{array}{l}\text { investigating the influence } \\
\text { of functionalization on the } \\
\text { separation of hexane iso- } \\
\text { mers }\end{array}$ \\
\hline 12 & $\begin{array}{l}\text { On the development of Vacuum Swing adsorp- } \\
\text { tion (VSA) technology for post-combustion } \\
\text { CO2capture }\end{array}$ & $\mathrm{UiO}-66 \mathrm{Zr}$ & CO2 capture \\
\hline 13 & $\begin{array}{l}\text { Conversion of levulinic acid into chemicals: } \\
\text { Synthesis of biomass derived levulinate esters } \\
\text { over Zr-containing MOFs }\end{array}$ & UiO-66, UiO-66-NH2 & $\begin{array}{l}\text { acid catalyzed esterifica- } \\
\text { tion of levulinic acid }\end{array}$ \\
\hline 14 & $\begin{array}{l}\text { Zirconium-based metal organic frameworks: } \\
\text { Highly selective adsorbents for removal of } \\
\text { phosphate from water and urine }\end{array}$ & UiO-66, UiO-66-NH2 & $\begin{array}{l}\text { Highly selective adsor- } \\
\text { bents for removal of } \\
\text { phosphate from water and } \\
\text { urine }\end{array}$ \\
\hline 15 & $\begin{array}{l}\text { Understanding the Thermodynamic and } \\
\text { Kinetic Behavior of the CO2/CH4Gas } \\
\text { Mixture within the Porous Zirconium } \\
\text { TerephthalateUiO-66(Zr): A Joint Experi- } \\
\text { mental and Modeling Approach }\end{array}$ & $\mathrm{UiO}-66 \mathrm{Zr}$ & $\begin{array}{l}\text { modeling was employed to } \\
\text { understand the coadsorp- } \\
\text { tion of CO2and } \mathrm{CH} 4 \text { from } \\
\text { both the thermodynamic } \\
\text { and kinetic points of view }\end{array}$ \\
\hline 16 & $\begin{array}{l}\text { Functionalization ofUiO-66Metal-Organic } \\
\text { Framework and Highly Cross-Linked } \\
\text { Polystyrene with } \mathrm{Cr}(\mathrm{CO}) 3 \text { : In Situ For- } \\
\text { mation, Stability, and Photoreactivity }\end{array}$ & $\mathrm{UiO}-66 \mathrm{Zr}-\mathrm{Cr}(\mathrm{CO}) 3$ & $\begin{array}{l}\text { Situ Formation, Stability, } \\
\text { and Photoreactivity }\end{array}$ \\
\hline 17 & $\begin{array}{l}\text { Stability of UiO- } 66 \text { under acidic treat- } \\
\text { ment: Opportunities and limitations for post- } \\
\text { synthetic modifications }\end{array}$ & $\mathrm{UiO}-66$ & $\begin{array}{l}\text { stable under acidic con- } \\
\text { ditions but not in the } \\
\text { presence of electrophilic } \\
\text { cationic species }\end{array}$ \\
\hline 18 & $\begin{array}{l}\text { Synthesis and hydrogen storage studies of } \\
\text { metal-organic framework UiO- } 66\end{array}$ & $\mathrm{UiO}-66$ & $\begin{array}{l}\text { Synthesis and hydrogen } \\
\text { storage studies }\end{array}$ \\
\hline 19 & $\begin{array}{l}\text { Nanosize Zr-metal organic framework (UiO- } \\
66 \text { ) for hydrogen and carbon dioxide storage }\end{array}$ & $\mathrm{UiO}-66$ & $\begin{array}{l}\text { hydrogen and carbon } \\
\text { dioxide storage }\end{array}$ \\
\hline
\end{tabular}




\begin{tabular}{|c|c|c|c|}
\hline 20 & $\begin{array}{l}\text { Effects of linker substitution on catalytic } \\
\text { properties of porous zirconium terephthalate } \\
\text { UiO-66 in acetalization of benzaldehyde with } \\
\text { methanol }\end{array}$ & $\mathrm{UiO}-66$ & $\begin{array}{l}\text { linker ligands on acid-base } \\
\text { and catalytic properties } \\
\text { was studied }\end{array}$ \\
\hline 21 & $\begin{array}{l}\text { Amino-functionalized } \mathrm{Zr}(\mathrm{IV}) \text { metal-organic } \\
\text { framework as bifunctional acid-base catalyst } \\
\text { for Knoevenagel condensation }\end{array}$ & UiO-66-NH2 & $\begin{array}{l}\text { catalyst for Knoevenagel } \\
\text { condensation }\end{array}$ \\
\hline 22 & $\begin{array}{l}\text { Disclosing the Complex Structure of UiO- } 66 \\
\text { Metal OrganicFramework: A Synergic Com- } \\
\text { bination of Experiment and Theory }\end{array}$ & $\mathrm{UiO}-66$ & $\begin{array}{l}\text { Synergic Combination of } \\
\text { Experiment and Theory }\end{array}$ \\
\hline 23 & $\begin{array}{l}\text { Superprotonic Conductivity of a UiO-66 } \\
\text { Framework Functionalized with Sulfonic Acid } \\
\text { Groups by Facile Postsynthetic Oxidation- }\end{array}$ & $\mathrm{UiO}-66(\mathrm{SO} 3 \mathrm{H}) 2$ & $\begin{array}{l}\text { conductivity exceeds that } \\
\text { of any proton-conducting } \\
\text { MOF reported to date }\end{array}$ \\
\hline 24 & $\begin{array}{l}\text { Studies on Photocatalytic CO2Reduction over } \\
\text { NH2-Uio-66(Zr) and Its Derivatives: Towards } \\
\text { a Better Understanding of Photocatalysis on } \\
\text { Metal-Organic Frameworks }\end{array}$ & NH2-Uio-66(Zr) & Photocatalysis \\
\hline 25 & $\begin{array}{l}\text { A Family of Metal-Organic Frameworks Ex- } \\
\text { hibiting Size-Selective Catalysis with Encap- } \\
\text { sulated Noble-Metal Nanoparticles }\end{array}$ & Pt/UIO-66 & Size-Selective Catalysis \\
\hline 26 & $\begin{array}{l}\text { Development of a SO3H-Functionalized UiO- } \\
66 \text { Metal-Organic Framework by Postsyn- } \\
\text { thetic Modification and Studies of Its Cat- } \\
\text { alytic Activities }\end{array}$ & $\mathrm{UiO}-66-\mathrm{NH} 2$ & $\begin{array}{l}\text { Postsynthetic Modifica- } \\
\text { tion and Studies of Its } \\
\text { Catalytic Activities }\end{array}$ \\
\hline 27 & $\begin{array}{l}\text { A General Strategy for the Synthesis of Func- } \\
\text { tionalised UiO-66 Frameworks: Characterisa- } \\
\text { tion, Stability and CO2Adsorption Properties }\end{array}$ & $\begin{array}{l}\mathrm{UiO}-66-\mathrm{X} \quad[\mathrm{X}=\mathrm{H}, \mathrm{F}, \\
\mathrm{F} 2, \mathrm{Cl}, \mathrm{Cl} 2, \mathrm{Br}, \mathrm{Br} 2, \\
\mathrm{I}, \mathrm{CH} 3, \quad(\mathrm{CH} 3) 2, \mathrm{CF} 3, \\
(\mathrm{CF} 3) 2, \mathrm{NO} 2, \mathrm{NH} 2, \mathrm{OH}, \\
(\mathrm{OH}) 2, \mathrm{OCH} 3,(\mathrm{CO} 2 \mathrm{H}) 2, \\
\mathrm{SO} 3 \mathrm{H}, \mathrm{C} 6 \mathrm{H} 4]\end{array}$ & $\begin{array}{l}\text { Stability and } \\
\text { CO2Adsorption Prop- } \\
\text { erties }\end{array}$ \\
\hline
\end{tabular}




\begin{tabular}{|c|c|c|c|}
\hline 28 & $\begin{array}{l}\text { Water Stable Zr-Benzenedicarboxylate Metal- } \\
\text { Organic Frameworks as Photocatalysts for } \\
\text { Hydrogen Generation }\end{array}$ & UiO-66 & $\begin{array}{l}\text { Photocatalysts for Hydro- } \\
\text { gen Generation }\end{array}$ \\
\hline 29 & $\begin{array}{l}\text { Photoinduced Postsynthetic Polymerization } \\
\text { of a Metal-Organic Framework toward a Flex- } \\
\text { ible Stand-Alone Membrane- }\end{array}$ & UiO-66-NH2 & $\begin{array}{l}\text { Flexible Stand-Alone } \\
\text { Membrane }\end{array}$ \\
\hline 30 & $\begin{array}{l}\text { Probing the Dynamics of CO2and CH4within } \\
\text { the Porous Zirconium Terephthalate UiO- } \\
66(\mathrm{Zr}) \text { : A Synergic Combination of Neutron } \\
\text { Scattering Measurements and Molecular Sim- } \\
\text { ulations }\end{array}$ & $\mathrm{UiO}-66(\mathrm{Zr})$ & $\begin{array}{l}\text { Neutron Scattering Mea- } \\
\text { surements and Molecular } \\
\text { Simulations }\end{array}$ \\
\hline 31 & $\begin{array}{l}\text { Deep desulfurization by oxidation using an ac- } \\
\text { tive ionic liquid-supported } \mathrm{Zr} \text { metal-organic } \\
\text { framework as catalyst }\end{array}$ & $\mathrm{UiO}-66(\mathrm{Zr})$ & catalyst \\
\hline 32 & $\begin{array}{l}\text { Kinetics study and crystallization process de- } \\
\text { sign for scale-up of UiO-66-NH2synthesis }\end{array}$ & $\mathrm{UiO}-66-\mathrm{NH} 2$ & $\begin{array}{l}\text { Kinetics Study and Crys- } \\
\text { tallization Process Design }\end{array}$ \\
\hline 33 & $\begin{array}{l}\text { Phosphotungstic acid encapsulated in metal- } \\
\text { organic framework UiO- } 66 \text { : An effective cata- } \\
\text { lyst for the selective oxidation ofcyclopentene } \\
\text { to glutaraldehyde }\end{array}$ & HPWs@UiO-66 & $\begin{array}{l}\text { catalyst for the selective } \\
\text { oxidation ofcyclopentene } \\
\text { to glutaraldehyde }\end{array}$ \\
\hline 34 & $\begin{array}{l}\text { Pilot-scale synthesis of a zirconium- } \\
\text { benzenedicarboxylate UiO-66 for } \\
\text { CO2adsorption and catalysis }\end{array}$ & $\mathrm{UiO}-66$ & $\begin{array}{l}\text { CO2adsorption and catal- } \\
\text { ysis }\end{array}$ \\
\hline 35 & $\begin{array}{l}\text { Selective adsorption of cationic dyes by UiO- } \\
66-\mathrm{NH} 2\end{array}$ & UiO-66-NH2 & $\begin{array}{l}\text { Selective adsorption of } \\
\text { cationic dyes }\end{array}$ \\
\hline 36 & $\begin{array}{l}\text { Efficient alkene epoxidation catalyzed by } \\
\text { molybdenyl acetylacetonate supported on am- } \\
\text { inated UiO- } 66 \text { metal-organic framework }\end{array}$ & UiO-66-NH2 & $\begin{array}{l}\text { alkene epoxidation cat- } \\
\text { alyzed }\end{array}$ \\
\hline
\end{tabular}




\begin{tabular}{|c|c|c|c|}
\hline 37 & $\begin{array}{l}\text { Structural study of Ni- or Mg-based complexes } \\
\text { incorporated within UiO-66-NH2framework } \\
\text { and their impact on hydrogen sorption prop- } \\
\text { erties }\end{array}$ & UiO-66-NH3 & $\begin{array}{l}\text { impact on hydrogen sorp- } \\
\text { tion properties }\end{array}$ \\
\hline 38 & $\begin{array}{l}\text { Preparation and enhanced CO2adsorption ca- } \\
\text { pacity of UiO-66/graphene oxide composites }\end{array}$ & $\mathrm{UiO}-66$ & $\begin{array}{l}\text { enhanced CO2adsorption } \\
\text { capacity }\end{array}$ \\
\hline 39 & $\begin{array}{l}\text { Adsorption Behavior of Rhodamine B on UiO- } \\
66\end{array}$ & $\mathrm{UiO}-66$ & $\begin{array}{l}\text { Adsorption, kinetics, ther- } \\
\text { modynamic, isotherm, re- } \\
\text { generation study }\end{array}$ \\
\hline 40 & $\begin{array}{l}\text { Adsorption and separation ofn-hexane and cy- } \\
\text { clohexane on the UiO- } 66 \text { metal-organic frame- } \\
\text { work }\end{array}$ & $\mathrm{UiO}-66$ & $\begin{array}{l}\text { Adsorption and separa- } \\
\text { tion ofn-hexane and cyclo- } \\
\text { hexane }\end{array}$ \\
\hline 41 & $\begin{array}{l}\text { Exceptional Mechanical Stability of Highly } \\
\text { Porous Zirconium Metal-Organic Framework } \\
\text { UiO-66 and Its Important Implications }\end{array}$ & $\mathrm{UiO}-66(\mathrm{Zr}, \mathrm{Hf}, \mathrm{Ti})$ & high mechanical stabilitie \\
\hline 42 & $\begin{array}{l}\text { A Modulated Hydrothermal (MHT) Approach } \\
\text { for the Facile Synthesis of UiO-66-Type } \\
\text { MOFs. }\end{array}$ & $\mathrm{UiO}-66$ & high water stability \\
\hline 43 & $\begin{array}{l}\text { Chemical Environment Control and Enhanced } \\
\text { Catalytic Performance of Platinum Nanopar- } \\
\text { ticles Embedded in Nanocrystalline Metal- } \\
\text { Organic Frameworks. }\end{array}$ & $\mathrm{UiO}-66$ & $\begin{array}{l}\text { Enhanced Catalytic Per- } \\
\text { formance }\end{array}$ \\
\hline 44 & $\begin{array}{l}\text { Highly Water Stable Zirconium Metal- } \\
\text { Organic } \\
\text { Supported on Alumina Hollow Fibers for } \\
\text { Desalination. }\end{array}$ & $\mathrm{UiO}-66$ & Highly Water Stable \\
\hline 45 & $\begin{array}{l}\text { Metal-organic framework nodes as nearly ideal } \\
\text { supports for molecular catalysts: NU-1000- } \\
\text { andUiO-66-supported iridium complexes. }\end{array}$ & UiO-66and NU-1000 & molecular catalysts \\
\hline
\end{tabular}




\begin{tabular}{|c|c|c|c|}
\hline 46 & $\begin{array}{l}\text { Impact of the Nature of the Organic Spacer } \\
\text { on the Crystallization Kinetics ofUiO- } 66(\mathrm{Zr})- \\
\text { Type MOFs. }\end{array}$ & $\mathrm{UiO}-66(\mathrm{Zr})$ & crystallization kinetics \\
\hline 47 & $\begin{array}{l}\text { Electronic effects of ligand substitution on } \\
\text { metal-organic framework photocatalysts: the } \\
\text { case study ofUiO- } 66 \text {. }\end{array}$ & $\begin{array}{l}\mathrm{UiO}-66-\mathrm{X}(\mathrm{X}=\mathrm{H}, \mathrm{NH} 2 \\
\mathrm{NO} 2, \mathrm{Br})\end{array}$ & $\begin{array}{l}\text { photocatalytic activity in } \\
\text { water treatment }\end{array}$ \\
\hline 48 & $\begin{array}{l}\text { Direct photo-hydroxylation of the Zr-based } \\
\text { frameworkUiO- } 66 \text {. }\end{array}$ & UiO-66 & photo-hydroxylation \\
\hline 49 & $\begin{array}{l}\text { Water adsorption inUiO-66: the importance } \\
\text { of defects. }\end{array}$ & $\mathrm{UiO}-66$ & Water adsorption \\
\hline 50 & $\begin{array}{l}\text { Inherent anchorages inUiO-66nanoparticles } \\
\text { for efficient capture of alendronate and its me- } \\
\text { diated release. }\end{array}$ & UiO-66 & $\begin{array}{l}\text { capture of alendronate } \\
\text { and its mediated release }\end{array}$ \\
\hline
\end{tabular}


Table A.4 Replacement of Zr/BDC in UiO-66 MOF

\begin{tabular}{|c|c|c|c|}
\hline No. & Title of Publication & MOF Formula Name & Application of MOF \\
\hline 1 & $\begin{array}{l}\text { Post-synthetic Ti Exchanged UiO-66 Metal- } \\
\text { Organic Frameworks that Deliver Exceptional } \\
\text { Gas Permeability in Mixed Matrix Membranes }\end{array}$ & $\mathrm{UiO}-66(\mathrm{Ti})$ & Gas seperation \\
\hline 2 & $\begin{array}{l}\text { Correlated defect nanoregions in a metal- } \\
\text { organic framework }\end{array}$ & Uio-66(Hf) & $\begin{array}{l}\text { storage, transport, optical } \\
\text { and mechanical responses }\end{array}$ \\
\hline 3 & $\begin{array}{l}\text { Reusable Oxidation Catalysis Using Metal- } \\
\text { Monocatecholato Species in a Robust Metal- } \\
\text { Organic Framework }\end{array}$ & $\begin{array}{l}\text { Uio- } \\
66(\mathrm{CAT}, \mathrm{K} 2 \mathrm{CrO} 4, \mathrm{CrCAT})\end{array}$ & $\begin{array}{l}\text { recyclable and reusable } \\
\text { oxidation catalysis }\end{array}$ \\
\hline 4 & $\begin{array}{l}\text { Enhanced Photochemical Hydrogen Produc- } \\
\text { tion by a Molecular Diiron Catalyst Incorpo- } \\
\text { rated into a Metal-Organic Framework }\end{array}$ & $\begin{array}{l}\text { UiO-66- } \\
{[\mathrm{FeFe}](\mathrm{dcbdt})(\mathrm{CO}) 6}\end{array}$ & $\begin{array}{l}\text { Enhanced Photochemical } \\
\text { Hydrogen Production }\end{array}$ \\
\hline 5 & $\begin{array}{l}\text { Photoinduced Postsynthetic Polymerization } \\
\text { of a Metal-Organic Framework toward a Flex- } \\
\text { ible Stand-Alone Membrane }\end{array}$ & $\mathrm{UiO}-66-\mathrm{NH} 2$ & $\begin{array}{l}\text { Enhanced Photochemical } \\
\text { Production }\end{array}$ \\
\hline 6 & $\begin{array}{l}\text { The effect of pore shape on hydrocarbon se- } \\
\text { lectivity on UiO-66(Zr), HKUST-1 and MIL- } \\
125(\mathrm{Ti}) \text { metal organic frameworks: Insights } \\
\text { from molecular simulations and chromatogra- } \\
\text { phy }\end{array}$ & $\begin{array}{l}\mathrm{UiO}-66(\mathrm{Zr}), \quad \text { HKUST-1 } \\
\text { and MIL-125(Ti) }\end{array}$ & Hydrocarbon selectivity \\
\hline 7 & $\begin{array}{l}\text { Noble-metal-free MoS2co-catalyst decorated } \\
\text { UiO-66/CdS hybrids for efficient photocat- } \\
\text { alytic H2production }\end{array}$ & MoS2/UiO-66/CdS & $\begin{array}{l}\text { efficient photocatalytic } \\
\text { H2production }\end{array}$ \\
\hline 8 & $\begin{array}{l}\text { Adsorption Behavior of Rhodamine B on UiO- } \\
66\end{array}$ & Uio-66+Benzoic acid & Light adsorption \\
\hline 9 & $\begin{array}{l}\text { Insights on the physical adsorption of hydro- } \\
\text { gen and methane in UiO series of MOFs using } \\
\text { molecular simulations }\end{array}$ & $\begin{array}{l}\text { UiO-66, UiO-67 and UiO- } \\
68\end{array}$ & $\begin{array}{l}\text { adsorption of hydrogen } \\
\text { and methane }\end{array}$ \\
\hline 10 & $\begin{array}{l}\text { Doping Metal-Organic Frameworks forWater } \\
\text { Oxidation, Carbon Dioxide Reduction, and } \\
\text { Organic Photocatalysis }\end{array}$ & Zr-Uio-67-bpdc & $\begin{array}{l}\text { developing highly active } \\
\text { heterogeneous catalysts } \\
\text { for solar energy utilization }\end{array}$ \\
\hline
\end{tabular}




\begin{tabular}{|c|c|c|c|}
\hline 11 & $\begin{array}{l}\text { A high surface area } \mathrm{Zr}(\mathrm{IV}) \text {-based metal- } \\
\text { organic framework showing stepwise gas ad- } \\
\text { sorption and selective dye uptake }\end{array}$ & $\begin{array}{l}\mathrm{UiO}-66, \mathrm{UiO}-67 \text { and } \mathrm{UiO}- \\
68\end{array}$ & $\begin{array}{l}\text { Higher surface area for } \\
\text { stepwise gas adsorption }\end{array}$ \\
\hline 12 & $\begin{array}{l}\text { Utilizing mixed-linker zirconium based metal- } \\
\text { organic frameworks to enhance the visible } \\
\text { light photocatalytic oxidation of alcohol }\end{array}$ & $\begin{array}{l}\text { UiO-66-X-BDC }(\mathrm{X}=\mathrm{H}, \mathrm{F} \\
\mathrm{Cl}, \mathrm{Br})\end{array}$ & $\begin{array}{l}\text { visible light photocat- } \\
\text { alytic oxidation of alcohol }\end{array}$ \\
\hline 13 & $\begin{array}{l}\text { Zirconium(IV) and hafnium(IV) coordination } \\
\text { polymers with a tetra-acetyl-ethane (Bisacac) } \\
\text { ligand: Synthesis, structure elucidation and } \\
\text { gas sorption behavior }\end{array}$ & $\begin{array}{l}\operatorname{Zr}(\text { Bisacac }) 2 \\
\operatorname{Hf}(\text { Bisacac }) 2\end{array}$ & $\begin{array}{l}\text { Synthesis, structure eluci- } \\
\text { dation and gas sorption } \\
\text { behavior }\end{array}$ \\
\hline 14 & $\begin{array}{l}\text { Acid-functionalized UiO-66(Zr) MOFs and } \\
\text { their evolution after intra-framework cross- } \\
\text { linking: structural features and sorption prop- } \\
\text { erties }\end{array}$ & $\begin{array}{l}\mathrm{UiO}-66(\mathrm{Zr})-(\mathrm{COOH}) \mathrm{x} \quad(\mathrm{x} \\
=1,2)\end{array}$ & $\begin{array}{l}\text { structural features and } \\
\text { sorption properties }\end{array}$ \\
\hline 15 & $\begin{array}{l}\text { Enhanced visible-light photocatalytic perfor- } \\
\text { mance of } \mathrm{BiOBr} / \mathrm{UiO}-66(\mathrm{Zr}) \text { composite for } \\
\text { dye degradation with the assistance of } \mathrm{UiO}- \\
66\end{array}$ & $\mathrm{BiOBr} / \mathrm{UiO}-66(\mathrm{Zr})$ & $\begin{array}{l}\text { Enhanced visible-light } \\
\text { photocatalytic perfor- } \\
\text { mance }\end{array}$ \\
\hline 16 & $\begin{array}{l}\text { Bismuth tungstate incorporated zirconium } \\
\text { metal-organic framework composite with en- } \\
\text { hanced visible-light photocatalytic perfor- } \\
\text { mance }\end{array}$ & Bi2WO6/UiO-66 & $\begin{array}{l}\text { enhanced visible-light } \\
\text { photocatalytic perfor- } \\
\text { mance }\end{array}$ \\
\hline 17 & $\begin{array}{l}\text { Introduction of a mediator for enhancing } \\
\text { photocatalytic performanceviapost-synthetic } \\
\text { metal exchange in metal-organic frameworks } \\
\text { (MOFs) }\end{array}$ & $\begin{array}{l}\text { Ti-substituted NH2-Uio- } \\
66(\mathrm{Zr} / \mathrm{Ti})\end{array}$ & $\begin{array}{l}\text { enhancing photocatalytic } \\
\text { performance }\end{array}$ \\
\hline 18 & $\begin{array}{l}\text { A route to drastic increase of CO2uptake in } \\
\text { Zr metal organic framework UiO- } 66\end{array}$ & $\mathrm{Ti}-\mathrm{UiO}-66$ & Uptake is almost doubled \\
\hline 19 & Au@UiO-66: a base free oxidation catalyst & $\mathrm{Au} @ \mathrm{UiO}-66$ & Catalyst \\
\hline
\end{tabular}




\begin{tabular}{|c|c|c|c|}
\hline 20 & $\begin{array}{l}\text { One-pot synthesis of UiO- } 66 @ \mathrm{SiO} 2 \text { shell-core } \\
\text { microspheres as stationary phase for high per- } \\
\text { formance liquid chromatography }\end{array}$ & UiO-66@SiO2 & $\begin{array}{l}\text { high performance liquid } \\
\text { chromatography }\end{array}$ \\
\hline 21 & $\begin{array}{l}\text { Computational exploration of newly syn- } \\
\text { thesized zirconium metal-organic frameworks } \\
\text { UiO-66, -67, - } 68 \text { and analogues }\end{array}$ & $\begin{array}{l}\text { UiO-66, }-67,-68 \text { and ana- } \\
\text { logues, Substituting TI } \\
\text { and } \mathrm{Hf} \text { for } \mathrm{Zr}\end{array}$ & $\begin{array}{l}\text { high surface area and ex- } \\
\text { ceptional thermal stabil- } \\
\text { ity, are resistant to water } \\
\text { and some solvents, acids, } \\
\text { bases, and remain crys- } \\
\text { talline at high pressure }\end{array}$ \\
\hline 22 & $\begin{array}{l}\text { Synthesis of a flower-like Zr-based metal- } \\
\text { organic framework and study of its catalytic } \\
\text { performance in the Mannich reaction }\end{array}$ & UiO-66-(COOH $) 2$ & $\begin{array}{l}\text { catalytic performance in } \\
\text { the Mannich reaction }\end{array}$ \\
\hline 23 & $\begin{array}{l}\text { Functionalization of robust } \mathrm{Zr}(\mathrm{IV}) \text {-based } \\
\text { metal-organic framework filmsviaa postsyn- } \\
\text { thetic ligand exchange }\end{array}$ & UiO-66-Fe2,CAT & reduced electrochemically \\
\hline 24 & $\begin{array}{l}\text { Highly dispersed palladium nanoparticles sup- } \\
\text { ported on amino functionalized metal-organic } \\
\text { frameworks as an efficient and reusable cata- } \\
\text { lyst for Suzuki cross-coupling reaction }\end{array}$ & $\mathrm{Pd} / \mathrm{Ui0}-66-\mathrm{NH} 2$ & catalyst \\
\hline 25 & $\begin{array}{l}\text { Postsyntheticligandexchange as a route to } \\
\text { functionalization of -inert- metal-organic } \\
\text { frameworks }\end{array}$ & $\mathrm{Zr}(\mathrm{IV})$-based UiO-66 & Ligand exchange \\
\hline 26 & $\begin{array}{l}\text { Enhanced selectivity of CO2over CH4in } \\
\text { sulphonate-, carboxylate- and iodo- } \\
\text { functionalized UiO- } 66 \text { frameworks }\end{array}$ & $\begin{array}{l}\mathrm{UiO}-66-\mathrm{X}(\mathrm{X}=-\mathrm{SO} 3 \mathrm{H}, 1 ; \\
-\mathrm{CO} 2 \mathrm{H}, 2 ;-\mathrm{I} ; 3\end{array}$ & $\begin{array}{l}\text { selectivity of CO2over } \\
\mathrm{CH} 4\end{array}$ \\
\hline 27 & $\begin{array}{l}\text { Postsynthetic modification at orthogonal reac- } \\
\text { tive sites on mixed, bifunctional metal-organic } \\
\text { frameworks }\end{array}$ & $\begin{array}{l}\text { UiO-66-(Br)(NH2), UiO- } \\
66-(\mathrm{CN})(\mathrm{AM} 1)\end{array}$ & $\begin{array}{l}\text { provides a facile route to a } \\
\text { large number of function- } \\
\text { ally diverse materials }\end{array}$ \\
\hline 28 & $\begin{array}{l}\text { Efficient molybdenum(VI) modified Zr-MOF } \\
\text { catalysts for epoxidation of olefins }\end{array}$ & $\begin{array}{l}\text { UiO-66-sal, UiO-66-sal- } \\
\mathrm{MoD}\end{array}$ & $\begin{array}{l}\text { catalysts for epoxidation } \\
\text { of olefins }\end{array}$ \\
\hline
\end{tabular}




\begin{tabular}{|c|c|c|c|}
\hline 29 & $\begin{array}{l}\text { Direct photo-hydroxylation of the Zr-based } \\
\text { framework UiO-66 }\end{array}$ & UiO-66-OH & Catalyst \\
\hline 30 & $\begin{array}{l}\text { Post-synthetic modification of the metal- } \\
\text { organic framework compoundUiO- } 66\end{array}$ & UiO-66-NHCOCH3 & $\begin{array}{l}\text { exceptional thermal sta- } \\
\text { bility }\end{array}$ \\
\hline 31 & $\begin{array}{l}\text { Synthesis of zeolite@metal-organic framework } \\
\text { core-shell particles as bifunctional catalysts }\end{array}$ & ZSM-5@UiO-66 & cascade reactions \\
\hline 32 & $\begin{array}{l}\text { An alternative } \mathrm{UiO}-66 \text { synthesis for } \mathrm{HCl}- \\
\text { sensitive nanoparticle encapsulation }\end{array}$ & $\mathrm{Zr}(\mathrm{OnPr}))$ & $\begin{array}{l}\text { synthesis route for pro- } \\
\text { ducing high-quality crys- } \\
\text { tals }\end{array}$ \\
\hline 33 & $\begin{array}{l}\text { Effect of pore sizes on catalytic activities of } \\
\text { arenetricarbonyl metal complexes constructed } \\
\text { within Zr-based MOFs }\end{array}$ & $\begin{array}{l}\mathrm{UiO}-66-\mathrm{Mo}(\mathrm{CO}) 3, \quad \mathrm{UiO}- \\
66-\mathrm{Cr}(\mathrm{CO}) 3\end{array}$ & $\begin{array}{l}\text { Effect of pore sizes on cat- } \\
\text { alytic activities }\end{array}$ \\
\hline 34 & $\begin{array}{l}\text { Photocatalytic CO2reduction by a mixed } \\
\text { metal }(\mathrm{Zr} / \mathrm{Ti}) \text {, mixed ligand metal-organic } \\
\text { framework under visible light irradiation }\end{array}$ & $\begin{array}{l}\text { mixed metal }(\mathrm{Zr} / \mathrm{Ti}) \mathrm{UiO}- \\
66\end{array}$ & $\begin{array}{l}\text { Photocatalytic } \mathrm{CO} 2 \text { re- } \\
\text { duction }\end{array}$ \\
\hline 35 & $\begin{array}{l}\text { A } \mathrm{Zr} \text { metal-organic framework based on } \\
\text { tetrakis(4-carboxyphenyl) silane and factors } \\
\text { affecting the hydrothermal stability of } \mathrm{Zr} \text { - } \\
\text { MOFs }\end{array}$ & UiO-66-TCPS & $\begin{array}{l}\text { affecting the hydrother- } \\
\text { mal stability }\end{array}$ \\
\hline 36 & $\begin{array}{l}\text { Tetrazine functionalized zirconium MOF as an } \\
\text { optical sensor for oxidizing gases }\end{array}$ & UiO-66(tz), UiO-66(dhtz) & $\begin{array}{l}\text { optical sensor for oxidizing } \\
\text { gases }\end{array}$ \\
\hline 37 & $\begin{array}{l}\text { Stability and degradation mechanisms of } \\
\text { metal-organic frameworks containing the } \\
\text { Zr6O4(OH)4 secondary building unit }\end{array}$ & $\mathrm{UiO}-67-\mathrm{SBU}$ & $\begin{array}{l}\text { susceptible to chemical } \\
\text { degradation bywaterand- } \\
\text { hydrochloric acid }\end{array}$ \\
\hline 38 & $\begin{array}{l}\text { A facile synthesis of UiO- } 66 \text {, UiO- } 67 \text { and their } \\
\text { derivatives }\end{array}$ & $\mathrm{UiO}-67$ & $\begin{array}{l}\text { yields exceptional porosi- } \\
\text { ties, and works with a } \\
\text { range of linkers }\end{array}$ \\
\hline 39 & $\begin{array}{l}\text { Zr-based metal-organic frameworks for spe- } \\
\text { cific and size-selective enrichment of phospho- } \\
\text { peptides with simultaneous exclusion of pro- } \\
\text { teins }\end{array}$ & $\mathrm{UiO}-68$ & $\begin{array}{l}\text { specific and size-selective } \\
\text { enrichment of phospho- } \\
\text { peptides with simultane- } \\
\text { ous exclusion of proteins }\end{array}$ \\
\hline
\end{tabular}




\begin{tabular}{|c|c|c|c|}
\hline 40 & $\begin{array}{l}\text { Defect-dependent colossal negative thermal } \\
\text { expansion in UiO-66(Hf) metal-organic frame- } \\
\text { work }\end{array}$ & UiO-66(Hf) & $\begin{array}{l}\text { strongest isotropic nega- } \\
\text { tive thermal expansion }\end{array}$ \\
\hline 41 & $\begin{array}{l}\text { In situgrowth of CdS nanoparticles on UiO- } \\
66 \text { metal-organic framework octahedrons for } \\
\text { enhanced photocatalytic hydrogen production } \\
\text { under visible light irradiation }\end{array}$ & $\mathrm{CdS} / \mathrm{UiO}-66$ & $\begin{array}{l}\text { enhanced photocatalytic } \\
\text { H2 generation under visi- } \\
\text { ble light irradiation }\end{array}$ \\
\hline 42 & $\begin{array}{l}\text { Preparation and evaluation of silica-UIO-66 } \\
\text { composite as liquid chromatographic station- } \\
\text { ary phase for fast and efficient separation }\end{array}$ & silica-UIO-66 composite & $\begin{array}{l}\text { liquid chromatographic } \\
\text { stationary phase for fast } \\
\text { and efficient separation }\end{array}$ \\
\hline 43 & $\begin{array}{l}\text { Modulated Synthesis of Zr-Based Metal- } \\
\text { Organic Frameworks: From Nano to Single } \\
\text { Crystals }\end{array}$ & $\begin{array}{l}\text { Zr-bdc (UiO-66), Zr- } \\
\text { bdc-NH2(UiO-66-NH2), } \\
\text { Zr-bpdc (UiO-67), and } \\
\text { Zr-tpdc-NH2(UiO-68- } \\
\text { NH2) }\end{array}$ & $\begin{array}{l}\text { first single-crystal struc- } \\
\text { tural analysis of a } \mathrm{Zr}- \\
\text { based MOF }\end{array}$ \\
\hline 44 & $\begin{array}{l}\text { Enhancing CO2Separation Ability of a Metal- } \\
\text { Organic Framework by Post-Synthetic Ligand } \\
\text { Exchange with Flexible Aliphatic Carboxy- } \\
\text { lates }\end{array}$ & $\begin{array}{l}\text { UiO-66-ADn:n=4, 6, 8, } \\
\text { and } 10\end{array}$ & $\begin{array}{l}\text { enhanced CO2uptake ca- } \\
\text { pacity }\end{array}$ \\
\hline 45 & $\begin{array}{l}\text { Ionic Conductivity in the Metal-Organic } \\
\text { Framework UiO- } 66 \text { by Dehydration and Inser- } \\
\text { tion of Lithiumtert-Butoxide }\end{array}$ & $\begin{array}{l}\text { UiO-66-Lithium } \\
\text { Butoxide }\end{array}$ & $\begin{array}{l}\text { enhancing the operation } \\
\text { of next-generation lithium } \\
\text { batteries }\end{array}$ \\
\hline 46 & $\begin{array}{l}\text { Titration of } \mathrm{Zr} 3(-\mathrm{OH}) \text { Hydroxy Groups at } \\
\text { the Cornerstones of Bulk MOF UiO-67, } \\
{[\mathrm{Zr} 6 \mathrm{O} 4(\mathrm{OH}) 4 \text { (biphenyldicarboxylate) } 6] \text {, and }} \\
\text { Their Reaction with }[\mathrm{AuMe}(\mathrm{PMe} 3)]\end{array}$ & $\mathrm{UiO}-67$ & $\begin{array}{l}\text { establish the UiO-66 fam- } \\
\text { ily as a very stable, well } \\
\text { defined, and chemically } \\
\text { well behaved set of mate- } \\
\text { rials }\end{array}$ \\
\hline 47 & $\begin{array}{l}\text { Multifunctional Metal-Organic Frameworks } \\
\text { for Photocatalysis }\end{array}$ & $\begin{array}{l}\mathrm{UiO}-66-\mathrm{Zr} 6 \mathrm{O} 4 \\
\text { (BDC,ATA) }\end{array}$ & Photocatalytic \\
\hline
\end{tabular}




\begin{tabular}{|c|c|c|c|}
\hline 48 & $\begin{array}{l}\text { Noble-metal-free MoS2co-catalyst decorated } \\
\text { UiO-66/CdS hybrids for efficient photocat- } \\
\text { alytic H2production }\end{array}$ & $\mathrm{UiO}-66 / \mathrm{CdS}$ & $\begin{array}{l}\text { efficient photocatalytic } \\
\text { H2production }\end{array}$ \\
\hline 49 & $\begin{array}{l}\text { Tuning the optical properties of the } \\
\text { zirconium-UiO- } 66 \text { metal-organic frame- } \\
\text { work for photocatalytic degradation of } \\
\text { methyl orange }\end{array}$ & $\mathrm{UiO}-66(\mathrm{AN})$ & $\begin{array}{l}\text { photocatalytic degrada- } \\
\text { tion of methyl orange }\end{array}$ \\
\hline 50 & $\begin{array}{l}\text { A high surface area } \mathrm{Zr}(\mathrm{IV}) \text {-based metal- } \\
\text { organic framework showing stepwise gas ad- } \\
\text { sorption and selective dye uptake }\end{array}$ & $\mathrm{UiO}-66($ eddb) & $\begin{array}{l}\text { stepwise gas adsorption } \\
\text { and selective dye uptake }\end{array}$ \\
\hline 51 & $\begin{array}{l}\text { Programming MOFs for water sorption: } \\
\text { amino-functionalized MIL- } 125 \text { and UiO- } 66 \text { for } \\
\text { heat transformation and heat storage applica- } \\
\text { tions. }\end{array}$ & $\begin{array}{l}\mathrm{UiO}-66(\mathrm{Zr}), \quad \mathrm{UiO}-67(\mathrm{Zr}), \\
\mathrm{H} 2 \mathrm{~N}-\mathrm{UiO}-66(\mathrm{Zr}) \quad \text { and } \\
\mathrm{H} 2 \mathrm{~N}-\mathrm{MIL}-125(\mathrm{Ti})\end{array}$ & water sorption \\
\hline 52 & $\begin{array}{l}\text { Computational exploration of newly syn- } \\
\text { thesized zirconium metal-organic frameworks } \\
\text { UiO-66,-67,-68 and analogues }\end{array}$ & Ti,Hf,Zr $(66,67,68)$ & $\begin{array}{l}\text { gas adsorption, storage, } \\
\text { and separation }\end{array}$ \\
\hline 53 & $\begin{array}{l}\text { Introduction of a mediator for enhancing } \\
\text { photocatalytic performanceviapost-synthetic } \\
\text { metal exchange in metal-organic frameworks } \\
\text { (MOFs) }\end{array}$ & NH2-Uio-66(Zr/Ti) & $\begin{array}{l}\text { enhancing photocatalytic } \\
\text { performance }\end{array}$ \\
\hline 54 & $\begin{array}{l}\text { A route to drastic increase of CO2uptake in } \\
\mathrm{Zr} \text { metal organic framework UiO- } 66\end{array}$ & $\mathrm{UiO}-66(\mathrm{Ti})$ & $\begin{array}{l}\text { drastic increase of } \\
\text { CO2uptake }\end{array}$ \\
\hline 55 & $\begin{array}{l}\text { Photocatalyticmetal-organic frameworks for } \\
\text { the aerobic oxidation of arylboronic acids. }\end{array}$ & $\mathrm{UiO}-67-\mathrm{Ru}(\mathrm{bpy}) 3$ & $\begin{array}{l}\text { efficient and recyclable } \\
\text { catalytic activity for the } \\
\text { aerobic oxidation }\end{array}$ \\
\hline 56 & $\begin{array}{l}\text { Defect-dependent colossal negative thermal } \\
\text { expansion inUiO-66(Hf) metal-organic frame- } \\
\text { work. }\end{array}$ & $\mathrm{UiO}-66(\mathrm{Hf})$ & $\begin{array}{l}\text { negative thermal expan- } \\
\text { sion }\end{array}$ \\
\hline
\end{tabular}




\begin{tabular}{||l|l|l|l||}
\hline 57 & $\begin{array}{l}\text { Superprotonic Conductivity of aUiO- } \\
66 \text { Framework Functionalized with Sulfonic } \\
\text { Acid Groups by Facile Postsynthetic Oxida- } \\
\text { tion. }\end{array}$ & $\begin{array}{l}\text { Superprotonic Conductiv- } \\
\text { ity }\end{array}$ \\
\hline 58 & $\begin{array}{l}\text { Pt@UiO-66heterostructures for highly selec- } \\
\text { tive detection of hydrogen peroxide with an } \\
\text { extended linear range. }\end{array}$ & Pt NPs@UiO-66 & $\begin{array}{l}\text { highly selective detection } \\
\text { of hydrogen peroxide with } \\
\text { an extended linear range. }\end{array}$ \\
\hline 59 & $\begin{array}{l}\text { Zr- andHf-based nanoscale metal-organic } \\
\text { frameworks as contrast agents for computed } \\
\text { tomography. }\end{array}$ & 66 & $\begin{array}{l}\text { Xixed metal (Hf/Ti) UiO-ray computed tomogra- } \\
\text { phy }\end{array}$ \\
\hline 60 & $\begin{array}{l}\text { Synthesis and characterization of amine- } \\
\text { functionalized mixed-ligand metal-organic } \\
\text { frameworks ofUiO-66topology. }\end{array}$ & $\begin{array}{l}\text { UiO-66-(ABDC/BDC) } \\
\text { Arganicframeworkfor } \\
\text { lightphotocatalytichydrogen production. }\end{array}$ & ultraviolet-visible \\
\hline 61 & $\begin{array}{l}\text { A dye-sensitized Pt@UiO-66(Zr)metal- } \\
\text { (Utispectroscopy }\end{array}$ \\
\hline
\end{tabular}




\section{APPENDIX B}

\section{Catalog of Catalytic MOFs}

Table B.1 Known Catalytic MOFs

\begin{tabular}{|c|c|c|c|}
\hline MOF Material & Substrate & Reaction Catalyzed & Ref. \\
\hline \multirow{2}{*}[\mathrm{Cd}(4\text{-btapa})2(\mathrm{NO}3)2]{} & Benzaldehyde and Malononitrile & $\begin{array}{l}\text { Knoevenagel Con- } \\
\text { densation }\end{array}$ & {$[36]$} \\
\hline & $\mathrm{C} 7 \mathrm{H} 6 \mathrm{O}$ and $\mathrm{C} 3 \mathrm{H} 2 \mathrm{~N} 2$ & -- & -- \\
\hline \multirow{2}{*}[\mathrm{Cd}(\mathrm{bpy})2]{$(\mathrm{NO} 3) 2)]$} & $\begin{array}{l}\text { Benzaldehyde and Trimethylsilyl } \\
\text { cyanide }\end{array}$ & $\begin{array}{l}\text { Cyanosilylation of } \\
\text { Aldehyde }\end{array}$ & {$[28]$} \\
\hline & C7H6O and C4H9NSi & -- & -- \\
\hline \multirow{2}{*}{ [Cd3Cl6(L1 )3] } & Acrolein and Diethylzinc & $\begin{array}{l}\text { Alkylation of Alde- } \\
\text { hyde }\end{array}$ & {$[37]$} \\
\hline & $\mathrm{C} 3 \mathrm{H} 4 \mathrm{O}$ and $\mathrm{C} 4 \mathrm{H} 10 \mathrm{Zn}$ & -- & - \\
\hline \multirow{2}{*}[\mathrm{Co}(\mathrm{BPB})]{} & Cyclohexene & Oxidation of Olefin & {$[38]$} \\
\hline & $\mathrm{C} 6 \mathrm{H} 10$ & -- & -- \\
\hline \multirow{4}{*}[\mathrm{Cr}3\mathrm{F}(\mathrm{H}2\mathrm{O})2\mathrm{O}(\mathrm{bdc})3]{} & $\begin{array}{l}\text { Benzaldehyde and Ethyl } \\
\text { cyanoacetate; }\end{array}$ & $\begin{array}{l}\text { Knoevenagel con- } \\
\text { densation; }\end{array}$ & {$[39]$} \\
\hline & Iodobenzene and Acrylic acid & -- & -- \\
\hline & $\mathrm{C} 7 \mathrm{H} 6 \mathrm{O}$ and $\mathrm{C} 5 \mathrm{H} 7 \mathrm{NO} 2$ & Heck coupling & -- \\
\hline & $\mathrm{C} 6 \mathrm{H} 5 \mathrm{I}$ and $\mathrm{C} 3 \mathrm{H} 4 \mathrm{O} 2$ & -- & -- \\
\hline \multirow{2}{*}{$\begin{array}{l}{[\mathrm{PW} 11 \mathrm{TiO} 40] 5-@[\mathrm{Cr} 3 \mathrm{~F}(\mathrm{H} 2 \mathrm{O}) 2 \mathrm{O}(\mathrm{bdc}) 3]} \\
\text { and }[\mathrm{PW} 11 \mathrm{CoO} 39] 5-@[\mathrm{Cr} 3 \mathrm{~F}(\mathrm{H} 2 \mathrm{O}) 2 \mathrm{O}(\mathrm{bdc}\end{array}$} & $\begin{array}{l}\text { a-Pinene, caryophyllene and cy- } \\
\text { clohexene }\end{array}$ & Oxidation of Olefin & {$[40]$} \\
\hline & $\mathrm{C} 10 \mathrm{H} 16, \mathrm{C} 15 \mathrm{H} 24$ and $\mathrm{C} 6 \mathrm{H} 10$ & -- & -- \\
\hline \multirow{2}{*}{$\begin{array}{l}\text { 3] } \\
{[\mathrm{Cu}(2 \text {-pymo }) 2] \text { and }[\mathrm{Co}(\mathrm{PhIM}) 2]}\end{array}$} & Tetralin & $\begin{array}{l}\text { Aerobic oxidation } \\
\text { of Olefin }\end{array}$ & {$[41]$} \\
\hline & $\mathrm{C} 10 \mathrm{H} 12$ & - & - \\
\hline \multirow{2}{*}[\mathrm{Cu}(\mathrm{bpy})(\mathrm{H}2\mathrm{O})2(\mathrm{BF}4)2(\mathrm{bpy})]{} & Various Epoxides & $\begin{array}{l}\text { Ring-opening of } \\
\text { Epoxide }\end{array}$ & {$[42]$} \\
\hline & -- & -- & -- \\
\hline
\end{tabular}




\begin{tabular}{|c|c|c|c|}
\hline \multirow[b]{2}{*}{$\mathrm{Cu}(\mathrm{D}$-asp $)$ bpe0 .5] and $[\mathrm{Cu}(\mathrm{L}$-asp $)$ bpe0 .5] } & $\begin{array}{l}\text { cis-2,3-Epoxybutane } \\
\text { methanol }\end{array}$ & $\begin{array}{l}\text { Methanolysis of } \\
\text { Epoxide }\end{array}$ & {$[26]$} \\
\hline & $\mathrm{C} 4 \mathrm{H} 8 \mathrm{O}$ and $\mathrm{CH} 4 \mathrm{O}$ & -- & -- \\
\hline \multirow{2}{*}{$\begin{array}{l}{[\mathrm{Cu}(\mathrm{L} 2) 2(\mathrm{H} 2 \mathrm{O}) 2],[\mathrm{Cu}(\mathrm{L} 3) 2(\mathrm{H} 2 \mathrm{O})(\mathrm{Py}) 2]} \\
{[\mathrm{Cu}(\mathrm{L} 3) 3(\mathrm{H} 2 \mathrm{O}) \mathrm{Cl}] \text { and }[\mathrm{Co}(\mathrm{sal})(\mathrm{H} 2 \mathrm{O})(\mathrm{Py}) 3]}\end{array}$} & Linear and cyclic olefins & $\begin{array}{l}\text { Epoxidation of } \\
\text { Olefin }\end{array}$ & {$[43]$} \\
\hline & -- & - & -- \\
\hline \multirow{2}{*}{$\begin{array}{l}{[\mathrm{Cu}(\mathrm{SO} 4)(\mathrm{pbbm})] \text { and }[(\mathrm{Cu}(\mathrm{Ac}) 2(\mathrm{pbbm}} \\
\left.))^{*} \mathrm{CH} 3 \mathrm{OH}\right]\end{array}$} & 2,6-Dimethylphenol & $\begin{array}{l}\text { Oxidative self- } \\
\text { coupling }\end{array}$ & {$[30]$} \\
\hline & $\mathrm{C} 8 \mathrm{H} 10 \mathrm{O}$ & - & - \\
\hline \multirow{5}{*}{ [Cu3(btc )2] } & $\begin{array}{l}\text { a-Pinene oxide; citronellal; ethy- } \\
\text { lene acetal of }\end{array}$ & Isomerization; & {$[44]$} \\
\hline & $\begin{array}{l}\mathrm{C} 10 \mathrm{H} 16 \mathrm{O} ; \mathrm{C} 10 \mathrm{H} 18 \mathrm{O} ; \mathrm{C} 6 \mathrm{H} 14 \mathrm{O} 2 \\
\text { of } \mathrm{C} 9 \mathrm{H} 9 \mathrm{BrO}\end{array}$ & $\begin{array}{l}\text { cyclization; rear- } \\
\text { rangement }\end{array}$ & -- \\
\hline & Olive oil and mill waste waters & $\begin{array}{l}\text { Oxidation of } \\
\text { polyphenol }\end{array}$ & {$[45]$} \\
\hline & $\begin{array}{l}\text { Benzaldehyde (or acetone) and } \\
\text { cyanotrimethylsilane }\end{array}$ & $\begin{array}{l}\text { Cyanosilylation of } \\
\text { aldehyde }\end{array}$ & {$[46]$} \\
\hline & $\begin{array}{l}\mathrm{C} 7 \mathrm{H} 6 \mathrm{O} \text { (or } \mathrm{C} 3 \mathrm{H} 6 \mathrm{O}) \text { and } \\
\mathrm{C} 4 \mathrm{H} 9 \mathrm{NSi}\end{array}$ & -- & -- \\
\hline \multirow{2}{*}[\operatorname{In}(\mathrm{OH})(\text{hippb})]{} & $\begin{array}{l}\text { Benzaldehyde and a- } \\
\text { methylbenzeneacetaldehyde }\end{array}$ & $\begin{array}{l}\text { Actualization of } \\
\text { aldehyde }\end{array}$ & {$[47]$} \\
\hline & $\mathrm{C} 7 \mathrm{H} 6 \mathrm{O}$ and $\mathrm{C} 9 \mathrm{H} 10 \mathrm{O}$ & - & -- \\
\hline \multirow{2}{*}[\operatorname{In}2(\mathrm{OH})3(\mathrm{bdc})1.5]{} & $\begin{array}{l}\text { Nitrobenzene and 2-methyl-1 } \\
\text { nitronaphthalene; methylphenyl } \\
\text { sulfide, (2-ethylbutyl) phenyl } \\
\text { sulfide }\end{array}$ & $\begin{array}{l}\text { Reduction of ni- } \\
\text { troaromatic; }\end{array}$ & {$[48]$} \\
\hline & $\begin{array}{l}\text { C6H5NO2 and C6H14ClNO2; } \\
\text { C14H14S, C24H34S }\end{array}$ & oxidation of sulfide & -- \\
\hline \multirow{3}{*}{ Mn(Porphyrin ) @[In48(HImDC )96] } & Cyclohexane & Oxidation of alkane & {$[49]$} \\
\hline & $\mathrm{C} 6 \mathrm{H} 12$ & - & - \\
\hline & Linalool & $\begin{array}{l}\text { Epoxidation } \\
\text { olefin }\end{array}$ & {$[50]$} \\
\hline
\end{tabular}




\begin{tabular}{|c|c|c|c|}
\hline$[\operatorname{Ln}(\mathrm{OH})(1,5$-nds $) \mathrm{H} 2 \mathrm{O}]$ & $\mathrm{C} 10 \mathrm{H} 18 \mathrm{O}$ & - & - \\
\hline \multirow{2}{*}{$\begin{array}{l}{[(\mathrm{Mn}(\mathrm{TpCPP}) \mathrm{Mn} 1.5)} \\
(\mathrm{C} 3 \mathrm{H} 7 \mathrm{NO}) * 5 \mathrm{C} 3 \mathrm{H} 7 \mathrm{NO}] \\
\end{array}$} & $\begin{array}{l}\text { Cyclic alkenes; cyclic/linear } \\
\text { alkanes }\end{array}$ & $\begin{array}{l}\text { Epoxidation of } \\
\text { olefin; }\end{array}$ & {$[51]$} \\
\hline & $\mathrm{CnH} 2 \mathrm{n}$ & oxidation of alkane & -- \\
\hline \multirow{2}{*}[\mathrm{Mn}3((\mathrm{Mn}4\mathrm{Cl})3(\mathrm{BTT})8(\mathrm{CH}3\mathrm{OH})10)]{2} & $\begin{array}{l}\text { Aldehydes and cyanotrimethylsi- } \\
\text { lane; benzaldehyde and acetal }\end{array}$ & $\begin{array}{l}\text { Cyanosilylation of } \\
\text { aldehyde; }\end{array}$ & {$[52]$} \\
\hline & $\begin{array}{l}\mathrm{RC}(=\mathrm{O}) \mathrm{H} \quad \text { and } \mathrm{C} 4 \mathrm{H} 9 \mathrm{NSi} ; \\
\mathrm{C} 7 \mathrm{H} 6 \mathrm{O} \text { and } \mathrm{C} 6 \mathrm{H} 14 \mathrm{O} 2\end{array}$ & Mukaiyama-aldol & - \\
\hline $\begin{array}{l}{[(\mathrm{Na} 20(\mathrm{Ni} 8 \mathrm{~L} 4} \\
13(\mathrm{CH} 3 \mathrm{OH}) 2]\end{array}$ & $\mathrm{CO}$ & Oxidation to $\mathrm{CO} 2$ & {$[53]$} \\
\hline \multirow{2}{*}[\mathrm{Pd}(2\text{-pymo})2]{} & $\begin{array}{l}\text { Cinnamyl alcohol; aryl halides } \\
\text { and aryl boronic acids; }\end{array}$ & $\begin{array}{l}\text { Oxidation } \\
\text { alcohol; } \quad \text { of } \\
\text { Miyauki- }\end{array}$ & {$[27]$} \\
\hline & $\begin{array}{l}\mathrm{C} 9 \mathrm{H} 10 \mathrm{O} ; \mathrm{C} 44 \mathrm{H} 27 \mathrm{NO} 2 \text { and } \\
\mathrm{H} 3 \mathrm{BO} 2 ; \mathrm{C} 8 \mathrm{H} 16, \mathrm{C} 12 \mathrm{H} 22\end{array}$ & $\begin{array}{l}\text { hydrogenation of } \\
\text { olefin }\end{array}$ & $\overline{--}$ \\
\hline \multirow{2}{*}{$\begin{array}{l}\mathrm{Tb}[\mathrm{V} 6 \mathrm{O} 13\{(\mathrm{OCH} 2) 3 \mathrm{C}(\mathrm{NH} 2 \mathrm{CH} 2 \mathrm{C} 6 \mathrm{H} 4-4-\mathrm{CO} 2 \\
)\}\{(\mathrm{OCH} 2) 3 \mathrm{C}-(\mathrm{NHCH} 2 \mathrm{C} 6 \mathrm{H} 4-4-\mathrm{CO} 2)\} 2] 4-\end{array}$} & Propanethiol & Oxidation of sulfide & {$[54]$} \\
\hline & C3H8S & - & - \\
\hline \multirow{2}{*}{ [Zn2(bpdc )2L5] } & 2,2-Dimethyl-2H-chromene & $\begin{array}{l}\text { Epoxidation of } \\
\text { olefins }\end{array}$ & {$[29]$} \\
\hline & $\mathrm{C} 11 \mathrm{H} 12 \mathrm{O}$ & - & -- \\
\hline \multirow{2}{*}[\mathrm{Zn}2(\mathrm{Py}2(\mathrm{PhF}5)2\text{PorZn)(TCPB})]{} & $\begin{array}{l}\text { Acetyl imidazole and Nicotinyl } \\
\text { alcohol }\end{array}$ & $\begin{array}{l}\text { Intermolecular } \\
\text { transfer of acyl } \\
\end{array}$ & {$[55]$} \\
\hline & $\mathrm{C} 5 \mathrm{H} 6 \mathrm{~N} 2 \mathrm{O}$ and $\mathrm{C} 6 \mathrm{H} 7 \mathrm{NO}$ & - & -- \\
\hline \multirow{2}{*}[\mathrm{Zn}3(\mathrm{u}3-\mathrm{O})(\mathrm{O}2\mathrm{CR})6(\mathrm{H}2\mathrm{O})3]{$\mathrm{n}+$} & Esters and alcohols & Transesterification & {$[56]$} \\
\hline & -- & -- & -- \\
\hline \multirow{2}{*}[\mathrm{Zn}4\mathrm{O}(\mathrm{bdc})3]{ and $[\mathrm{Zn} 4 \mathrm{O}(\mathrm{nds}) 3]$} & tert-Butyl chloride and toluene & $\begin{array}{l}\text { Friedel-Crafts alky- } \\
\text { lation }\end{array}$ & {$[25]$} \\
\hline & $\mathrm{C} 4 \mathrm{H} 9 \mathrm{Cl}$ and $\mathrm{C} 7 \mathrm{H} 8$ & - & - \\
\hline \multirow{2}{*}[(\mathrm{Zn}4\mathrm{O})(\mathrm{bdc}-\mathrm{NH}2)3]{$^{*}$ Vsal 0.4} & Cyclohexene & Oxidation of olefin & {$[26]$} \\
\hline & $\mathrm{C} 6 \mathrm{H} 10$ & - & $\overline{--}$ \\
\hline
\end{tabular}


Table B.2 Reference Material

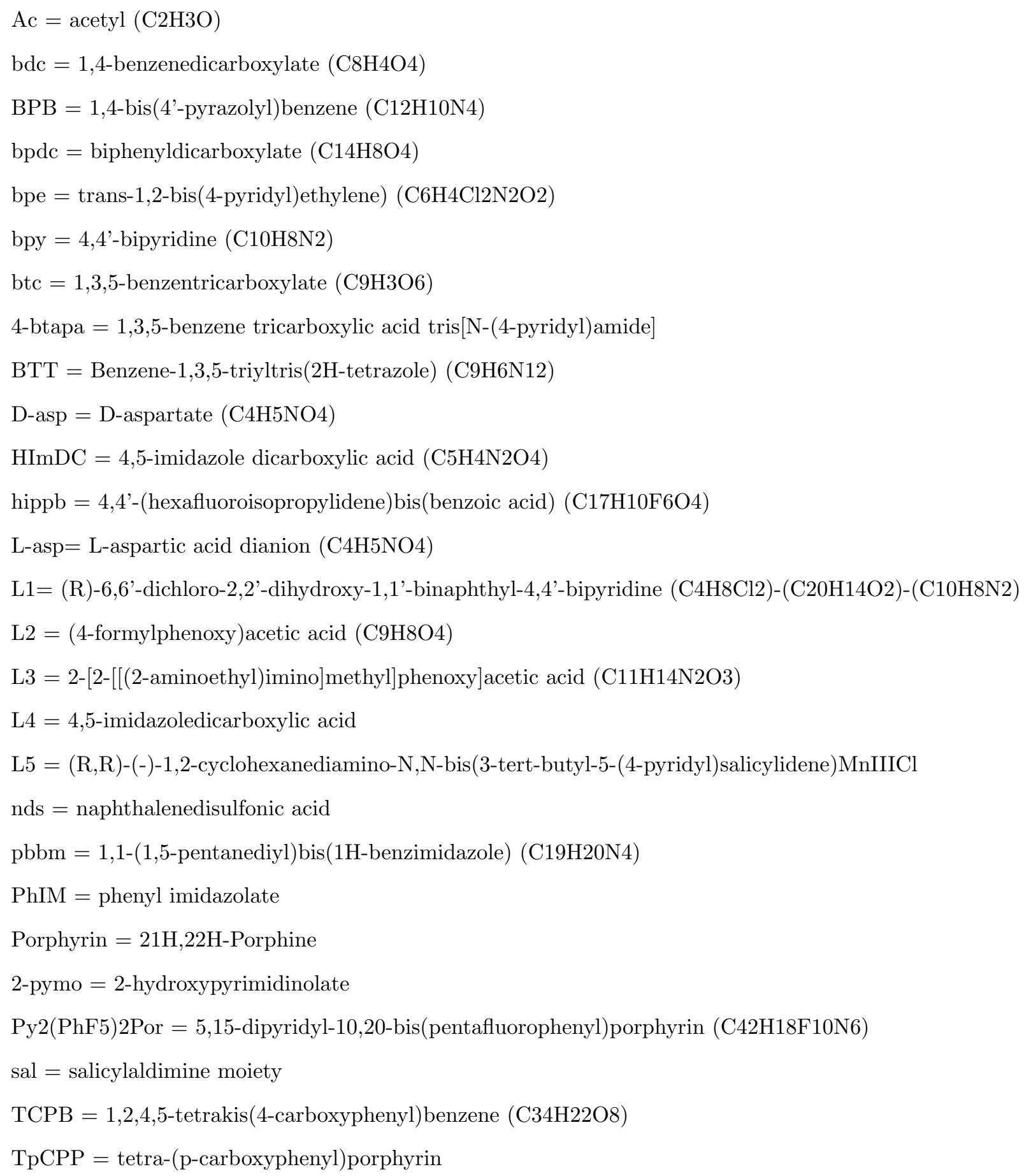

